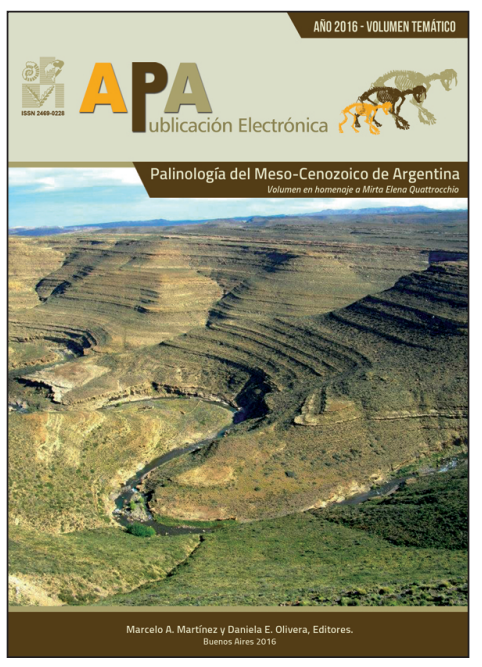

\title{
JURASSIC ORGANIC-WALLED MARINE MICROPLANKTON FROM THE NEUQUÉN BASIN. DISTRIBUTION, BIOSTRATIGRAPHY AND PALEOBIOGEOGRAPHY. A REVIEW
}

MARCELO A. MARTÍNEZ ${ }^{1,2}$

DANIELA E. OLIVERA ${ }^{1,2}$

\begin{abstract}
${ }^{1}$ Instituto Geológico del Sur-CONICET/Departamento de Geología (UNS), San Juan 670, B8000ICN Bahía Blanca, Buenos Aires, Argentina. ²Universidad Nacional del Sur, Departamento de Geología, San Juan 670, B8000ICN Bahía Blanca, Buenos Aires, Argentina.
\end{abstract}

Recibido: 29 de abril de 2016 - Aceptado: 25 de noviembre de 2016

Para citar este artículo: Marcelo A. Martínez and Daniela E. Olivera (2016). Jurassic organic-walled marine microplankton from the Neuquén Basin. Distribution, biostratigraphy and paleobiogeography. A review. En: M. Martínez y D. Olivera (Eds.), Palinología del Meso-Cenozoico de Argentina - Volumen en homenaje a Mirta Elena Quattrocchio. Publicación Electrónica de la Asociación Paleontológica Argentina 16 (2): 106-128.

Link a este artículo: http://dx.doi.org/10.5710/PEAPA.25.11.2016.115

DESPLAZARSE HACIA ABAJO PARA ACCEDER AL ARTÍCULO

Asociación Paleontológica Argentina Maipú $6451^{\circ}$ piso, C1006ACG, Buenos Aires República Argentina Tel/Fax (54-11) 4326-7563 Web: www.apaleontologica.org.ar

Otros artículos en Publicación Electrónica de la APA 16(2):

\section{Borromei et al.}

POSTGLACIAL VEGETATION AND CLIMATE CHANGES INFERRED FROM A PEAT POLLEN RECORD IN THE RÍO PIPO VALLEY, SOUTHERN TIERRA DEL FUEGO

\section{Deschamps \& Tomassini}

LATE CENOZOIC VERTEBRATES FROM THE SOUTHERN PAMPEAN REGION: SYSTEMATIC AND BIO-CHRONOSTRATIGRAPHIC UPDATE

\section{Prieto}

ANÁLISIS E INTERPRETACIÓN DE REGISTROS PALINOLÓGICOS DE SUCESIONES ALUVIALES DE LA REGIÓN PAMPEANA: REVISIÓN E IMPLICANCIAS PARA LA RECONSTRUCCIÓN DE LA VEGETACIÓN Y EL CLIMA DURANTE EL PLEISTOCENO TARDIO - HOLOCENO 


\title{
JURASSIC ORGANIC-WALLED MARINE MICROPLANKTON FROM THE NEUQUÉN BASIN. DISTRIBUTION, BIOSTRATIGRAPHY AND PALEOBIOGEOGRAPHY. A REVIEW
}

\author{
MARCELO A. MARTÍNEZ ${ }^{1,2,}$ AND DANIELA E. OLIVERA ${ }^{1,2}$
}

1'Instituto Geológico del Sur-CONICET/Departamento de Geología (UNS), San Juan 670, B8000ICN Bahía Blanca, Buenos Aires, Argentina. martinez@criba.edu.ar ²Universidad Nacional del Sur, Departamento de Geología, San Juan 670, B8000ICN Bahía Blanca, Buenos Aires, Argentina.daniela.olivera@uns.edu.ar

\begin{abstract}
The Mesozoic Era is crucial for analyzing the replacement of microplanktonic lineages resulting from the beginning of the break-up of Pangea. The paleogeography of South America, and hence of Argentina, underwent successive changes since this time. The opening of different seaways, mainly during the Jurassic, affected the global circulation pattern of the oceans which determined the composition of the organic-walled marine microplankton associations of the Neuquén Basin. These Jurassic marine palynofloras are summarized here, based on the information from outcrop samples of 12 units, which were analyzed from a paleobiogeographic point of view. The configuration of the basin during the Early Jurassic was characterized mainly by partially interconnected depocenters, with restricted marine circulation that favored the development of associations dominated by components of the green lineage (acritarchs and prasinophytes). The Cuyo and Lotena groups (Middle Jurassic) were accumulated during two important flooding episodes which generated the paleoecological conditions for an increase in the diversity of the red lineage (dinocysts). Since the late Callovian the Hispanic Corridor connected the Neuquen Basin with the Tethyan realm allowing the free interchange of species. The Late Jurassic marine palynofloras are best characterized in the Vaca Muerta and Picún Leufú formations. The anoxic condition that prevailed during the accumulation of the Vaca Muerta Formation marked the return to the dominance of the green lineage. Conversely, the Picún Leufú Formation represents neritic more oxygenated bottom waters that favored a relative increase in the abundance and diversity of dinoflagellate cysts.
\end{abstract}

Key words. Jurassic. Marine palynofloras. Paleobiogeography. Neuquén Basin. Argentina.

Resumen. MICROPLANCTON MARINO DE PARED ORGÁNICA, JURÁSICO DE LA CUENCA NEUQUINA. DISTRIBUCIÓN, BIOESTRATIGRAFÍA Y PALEOBIOGEOGRAFÍA. UNA REVISIÓN. El Mesozoico constituye un momento crucial para analizar el recambio de los distintos linajes microplanctónicos producto del inicio de la ruptura de Pangea. La paleogeografía de Sudamérica y por lo tanto la de Argentina, experimentó sucesivos cambios durante este lapso de tiempo. La apertura de diferentes corredores oceánicos, principalmente durante el Jurásico, afectó los patrones de circulación global de los océanos, evidenciado en la Cuenca Neuquina en la variabilidad de composición de las asociaciones microplanctónicas de pared orgánica. Se reúne la información proveniente de muestras de afloramiento de 12 unidades jurásicas, cuyas palinofloras marinas fueron analizadas desde un punto de vista paleobiogeográfico. La configuración de la cuenca durante el Jurásico Temprano se caracterizó principalmente por la presencia de una serie de depocentros parcialmente interconectados con circulación marina restringida. Este contexto favoreció el desarrollo del linaje verde (acritarcos y prasinofíceas). Dos grandes episodios de inundación marina provocaron la acumulación de los grupos Cuyo y Lotena (Jurásico Medio) generando las condiciones paleoecológicas para un incremento en la diversidad del linaje rojo (dinoquistes). A partir del Caloviano tardío la apertura del Corredor Hispánico permitió la conexión de la Cuenca Neuquina con el Dominio Tethiano y con ello, el libre intercambio de especies. El Jurásico Tardío es aquí caracterizado por las palinofloras marinas de las formaciones Vaca Muerta y Picún Leufú. Las condiciones anóxicas que prevalecieron durante la acumulación de la Formación Vaca Muerta constituyen un retorno al predominio del linaje verde. Por el contrario, la Formación Picún Leufú caracterizada por ambientes de plataforma con aguas relativamente más oxigenadas, favorecieron el incremento en la abundancia y diversidad de dinoflagelados.

Palabras clave. Jurásico. Palinofloras marinas. Paleobiogeografía. Cuenca Neuquina. Argentina.

THE FOSSIL record of the Paleozoic-Mesozoic boundary documents one of the most dramatic changes in Phanerozoic marine primary production. It is generally agreed that acritarchs and prasinophytes essentially represent the ma- rine phytoplankton of the Paleozoic Era (Riegel, 2008 and references therein). These groups were included by several authors (Falkowski et al., 2005; Riegel, 2008 and references therein) in the "green lineage". Highly stratified anoxic bottom 
water overlain by low-salinity, warm surface waters were advantageous conditions for green algae (van de Schootbrugge et al., 2005).

During the Middle-Late Triassic new groups of photosynthetic eukaryotic phytoplankton taxa, including cystforming dinoflagellates and calcareous nannoplankton (coccolithophorids), appeared (Riegel, 2008 and references therein), which represent the "red lineage" (Falkowski et al., 2005 in van de Schootbrugge et al., 2005). The radiation of cyst-forming dinoflagellates began in the Late Triassic showing a rapid increase during the Early Jurassic (Fensome et al., 1996). This time was decisive for dinoflagellate evolution and during the late Pliensbachian they replaced green algae as primary producers. The break-up of Pangea played a crucial role in the spread of the red lineage (Katz et al., 2004 in Riegel, 2008). The radiation of cyst-forming dinoflagellates during the late Sinemurian and late Pliensbachian coincided with significant changes in paleoceanography and paleoclimate, possibly related to the opening and flooding of the Hispanic Corridor (van de Schootbrugge et al., 2005). Hydrographic instabilities and well-oxygenated bottom waters appear to have facilitated cyst-forming dinoflagellate diversity (Bucefalo Palliani et al., 2002; van de Schootbrugge et al., 2005; Sluijs et al., 2005).

The main goal of this contribution is to describe the way these worldwide paleoceanographic changes affected the distribution and diversity patterns of organic-walled marine microplankton in the Neuquén Basin, Argentina, during the Jurassic.

\section{GEOLOGICAL SETTING OF THE NEUQUÉN BASIN}

The Neuquén Basin is situated in west-central Argentina and eastern Chile between $34^{\circ}$ and $41^{\circ} \mathrm{S}$ (Fig. 1). This basin, originated during the latest Triassic, was an important region of sedimentation during the Jurassic and Early Cretaceous (Mpodozis and Ramos, 1989). It has been interpreted as a back-arc basin related to the thermal-tectonic collapse of the continental crust behind a stationary magmatic arc during the Late Triassic (Mpodozis and Ramos, 1989; Vergani et al., 1995).

Permo-Triassic volcaniclastics, constituting the Choiyoi Group (Groeber, 1946; Stipanicic et al., 1968) are regarded as basement. Deposits are mainly marine in origin and present well-defined records of cyclic sea-level changes at different scales (Howell et al., 2005). The first major depositional episode after the basin was configured, the Cuyo Group (Groeber, 1946), comprises marine and continental deposits more than 2500 m thick, accumulated during a transgressive-regressive cycle which developed during the Hettangian-Middle Callovian (Zavala, 1996a). Although a Hettangian-Sinemurian marine transgression with ammonite fauna is recorded at the Río Atuel, Mendoza Province (Riccardi et al., 1988), it did not reach the central and southern Neuquén Basin until the Pliensbachian. This group is composed of deposits consisting of a prograding clastic section with offshore fine-grained deposits of the Los Molles Formation (Weaver, 1931) (Fig. 2), isolated turbidite intervals and hyperpycnal flows (Zavala et al., 2011, 2014; Martínez et al., 2016). This formation is progressively overlain by sandstones and conglomerates reflecting shallow marine to continental environments belonging to the Lajas Formation (Weaver, 1931).

During the Early-Middle Jurassic the presence of a tectonic structure controlled the acumulation in the basin. This extensive and complex east-west oriented Mesozoic structure named Huincul Arch, located in the southern part of the Neuquén Basin, acted as a physical barrier isolating this part of the basin as a sub-basin named Picún Leufú (Hogg, 1993; Zavala and Freije, 2002). In this sub-basin the deposition of the Cuyo Group culminates with the continental deposits, red mudstones interbedded with sandstones and conglomerates, of the Challacó Formation (de Ferrariis, 1947; Zavala and González, 2001).

The Lotena Group (sensu Zavala and González, 2001) represents the second marine incursion after the first broad disconnection (Zavala, 2005). It is a clastic-evaporitic unit deposited during the middle Callovian until the latest Oxfordian-Early Kimmeridgian (Zavala 2005; Olivera et al., 2010). This group starts with evaporites of the Tábanos Formation (Stipanicic, 1966; Dellapé et al., 1979) followed by the Lotena Formation (sensu Gulisano et al., 1984) (Fig. 2), which is dominated by mudstone with subordinate evaporites, limestones and sandstones. This unit is overlain by the mainly carbonate succession of the La Manga Formation (Stipanicic, 1966; Stipanicic et al., 1975). The partial isolation of the Picún Leufú sub-basin continued during the be- 


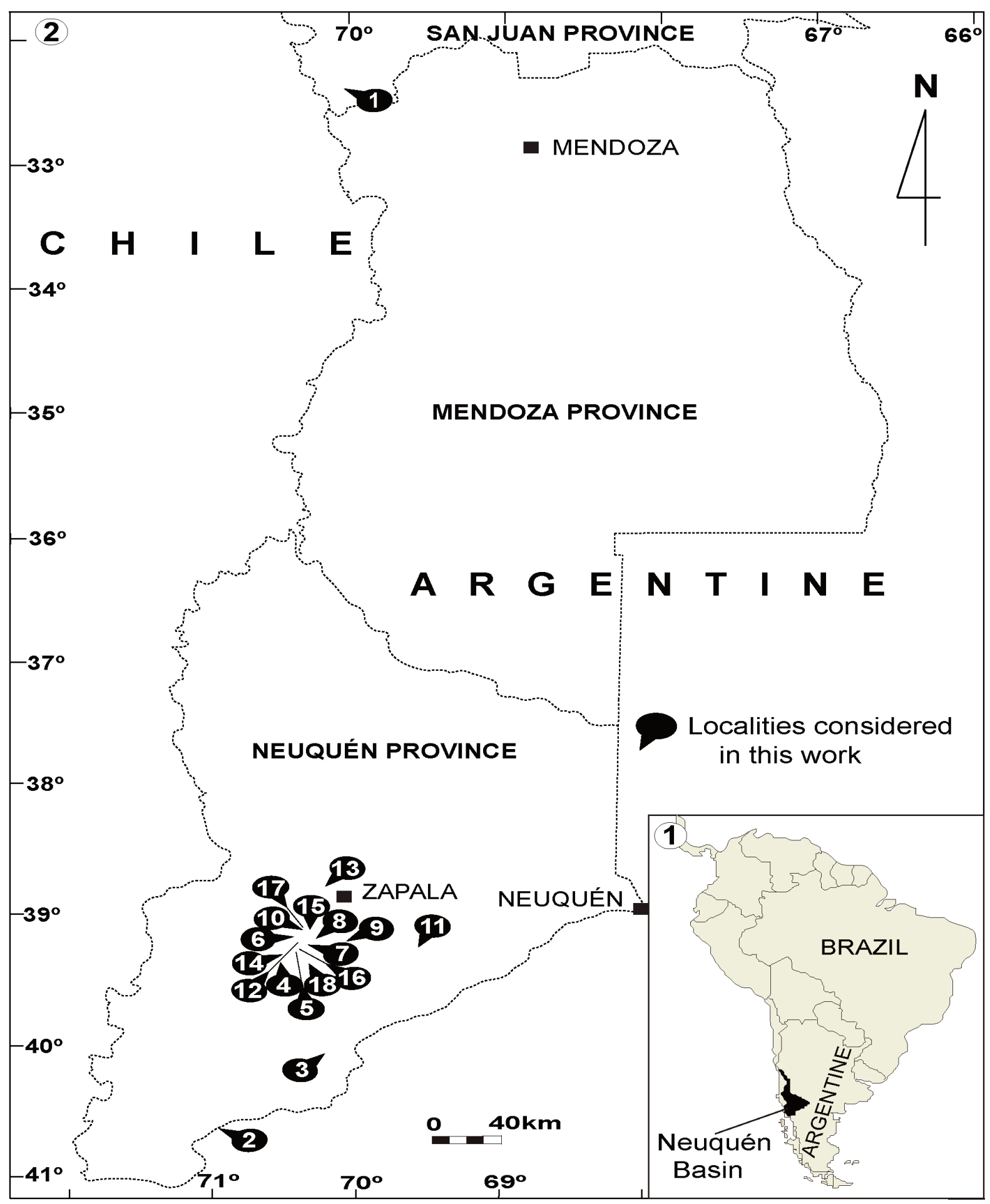

Figure 1. 1, Location map of the Neuquén Basin, Argentina, South America. 2, Localities mentioned in the text; 1, Arroyo de los Patos Sur (Los Patillos Fm.); 2, Alicurá Dam (Nestares Fm.); 3, Cañadón La Pintada (Piedra Pintada Fm.); 4, Valle del Arroyo Lapa (Sierra Chacaico Fm.) and Arroyo Lapa-Estancia Charahuilla (Los Molles Fm.); 5, Charauilla (Los Molles and Lajas formations); 6, Puesto Bascuñán (Lajas Fm.); 7, Puesto Policía (Los Molles Fm.); 8, Los Molles (Los Molles and Lajas formations); 9, Puente Picún Leufú (Los Molles, Lajas, Lotena, Vaca Muerta and Picún Leufú formations); 10, Lohan Mahuida (Los Molles, Cura Niyeu and Lajas formations); 11, Cerro Lotena (Los Molles Fm.); 12, Cerro Chacaico (Los Molles and Lajas formations); 13, Portada Covunco (Lajas, Lotena and Auquilco formations); 14, Sierra Chacaico: Peregrina, Rhea Gorge, Quilmez and Dagna (Lajas Fm.); 15, Quebrada del Sapo (Bosque Petrificado Fm.); 16, Cura Niyeu (Cura Niyeu Fm.); 17, Barda Norte (Lotena Fm.); 18, Caichigüe (Vaca Muerta Fm.). 
ginning of the accumulation of the Lotena Group. These deposits represent fluvial-lacustrine to estuarine enviroments and are known as the Bosque Petrificado Formation (Zavala and Freije, 2002), which is chronologically, but not genetically, related to the Tábanos Formation (Zavala and González, 2001; Zavala and Freije, 2002).

Marine sequences developed throughout the basin during the Late Jurassic-Early Cretaceous are included in the Mendoza Group (Stipanicic, 1969). This group comprises several units, the Auquilco (Weaver, 1931), Tordillo (Groeber, 1946; Stipanicic, 1966), Quebrada del Sapo (Digregorio, 1972), Vaca Muerta (Leanza and Hugo, 1978; Legarreta et al., 1981; Veiga and Orchuela, 1988), Picún Leufú (Leanza 1973), Quintuco (Digregorio, 1972), Mulichinco (Digregorio, 1972) and Agrio (Weaver, 1931) formations widely extending from southern Neuquén to Mendoza provinces. The Auquilco Formation comprises an evaporitic succession of up to $400 \mathrm{~m}$ thick related to a marginal hypersaline marine environment (Legarreta and Uliana 1999; Volkheimer and Moroni 1981). The continental deposits of the Tordillo and Quebrada del Sapo formations represent a temporal isolation of the Neuquén Basin from the Pacific Ocean. During the Tithonian, catastrophic flooding represents the return to a depositional context of a marine basin with anoxic bottom water (Legarreta and Uliana, 1999), which corresponds to the deposits of the Vaca Muerta Formation. The top of this unit is diachronous and progradational. It includes younger stages when passing from the southern (middle Tithonian) to the central sector of the basin (BerriasianValanginian) (Doyle et al., 2005). Near the southern border of the basin, the Vaca Muerta Formation is replaced laterally by the whitish and greenish calcareous sandstones, and massive whitish limestones of the Picún Leufú Formation.
All the units mentioned in this contribution are summarized in a correlation chart between two geological provinces, Principal Cordillera and Neuquén Embayment (Fig. 2).

\section{PALEOGEOGRAPHIC FRAMEWORK}

The paleogeography of the beginning of the Jurassic was similar to the one of the end of the Paleozoic (Fig. 3). The supercontinent Pangea, surrounded by the superocean Panthalassa, represented a large barrier to the free movement of marine biotas along the paleo-equator. However, a system of rift valleys started to form within west-central Pangea since the latest Triassic (Iturralde-Vinent, 2006). In this area, Damborenea and Manceñido (1979) proposed the existence of a shallow intermittent marine connection between western Tethys and the eastern Pacific, based on bivalve data. This seaway, known as the Hispanic Corridor (Smith, 1983) acted as a filter which only allowed the interchange of on-shore benthonic species since the Sinemurian (Damborenea, 2000). The effective opening of this marine passage was installed during the Middle Jurassic. The stratigraphic record indicates that this connection was fully functional and the Circum-Tropical marine current was probably active since the Bathonian and certainly since the Oxfordian (Iturralde-Vinent, 2004, 2006).

By the late Pliensbachian another seaway, called the Viking Corridor by Westermann (1993), was opened between Greenland and Norway connecting the Arctic and Tethys oceans (Aberhan, 2001).

Another migration route was established during the Middle Jurassic (Bathonian and Callovian) with the opening of the Mozambique Corridor (Heinze, 1996; Abdelhady and Fürsich, 2015), which communicated Madagascar and

Figure 2. Correlation chart of selected Jurassic units from two geological provinces of Argentina. They are organized in integrated columns; only the main depocenters of these regions are taken into account, and they do not represent the entire units of each basin. The age range of each formation is mainly based on paleontological works (palynomorphs and ammonoids fossil-genera): La Ramada Basin: Volkheimer et al. (1977), Álvarez et al. (1994), Álvarez (1996); Río Atuel: Dimieri et al. (2005); Northward of Huincul Arch: Volkheimer and Moroni (1981), Zavala (1996 a,b), Martínez (2002), Martínez et al. (2005); Picún Leufú Sub-basin: Volkheimer (1973), Arguijo et al. (1982), González-Amicón and Volkheimer (1982a,b), Zavala and Freije (2002), Zavala et al. (2005), Armella et al. (2007), Zavattieri et al. (2008), Olivera et al. (2010). Abbreviations in the graphic: CN, Cura Niyeu Formation; BP, Bosque Petrificado Formation; FM, Fortín Primero de Mayo Formation; QS, Quebrada del Sapo Formation; T, Tordillo Formation; VM (part.), Vaca Muerta Formation (partially); PL (part.), Picún Leufú Formation (partially). 


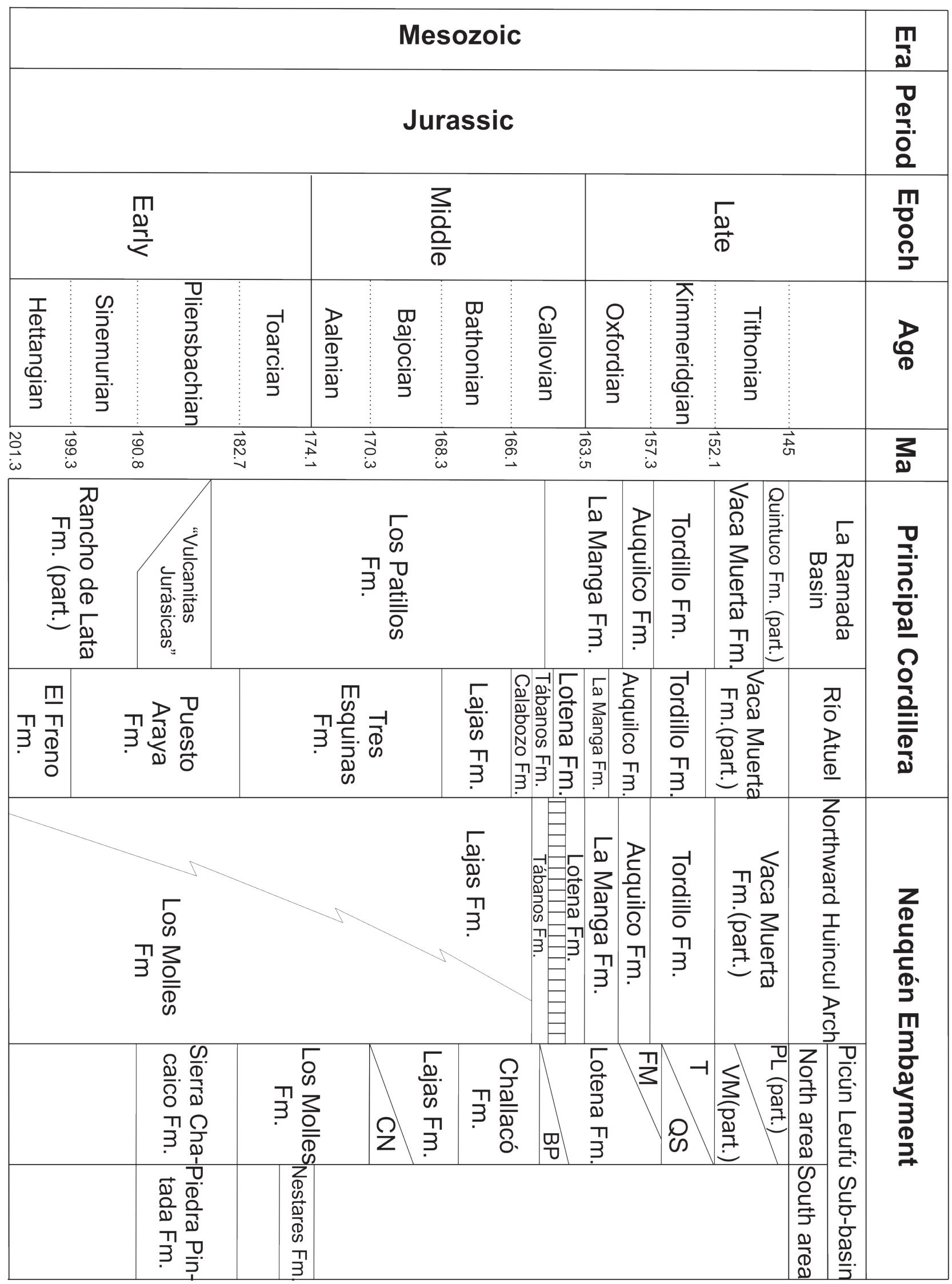




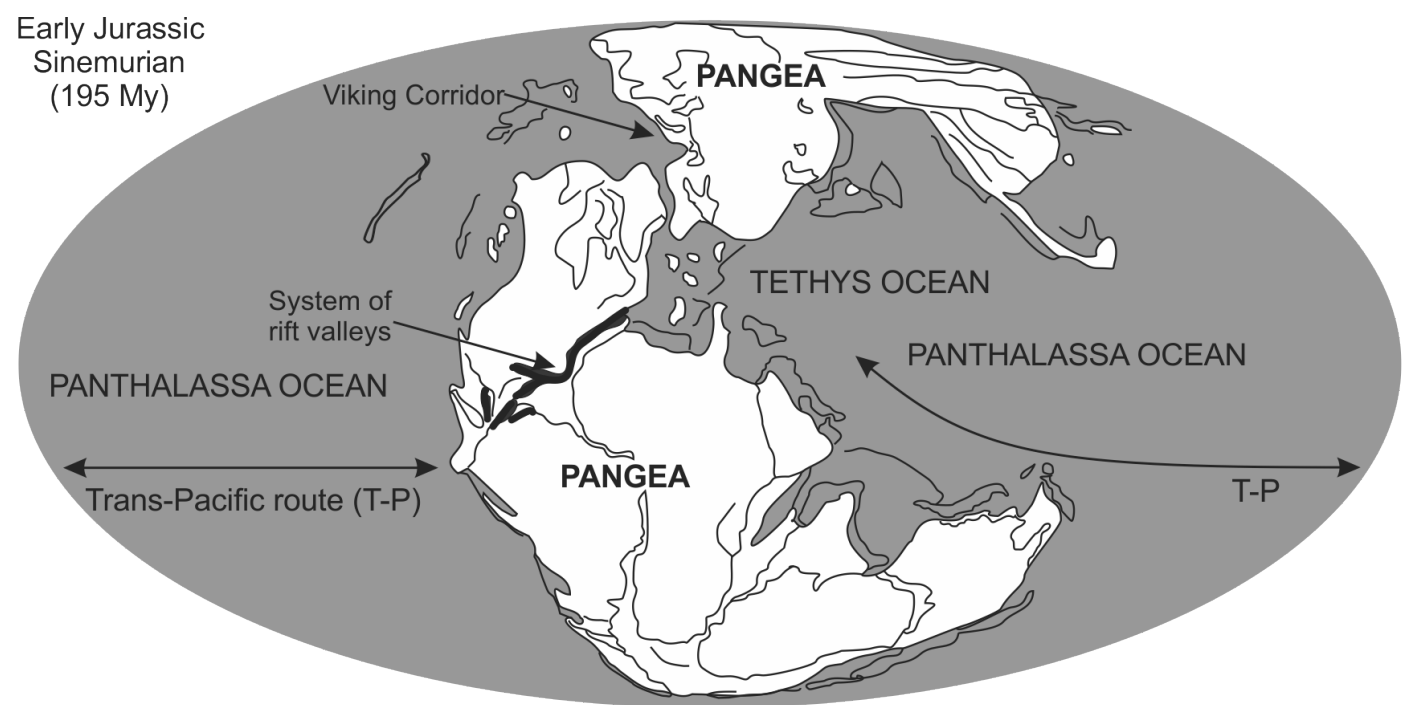

Middle Jurassic Bajocian (170 My)

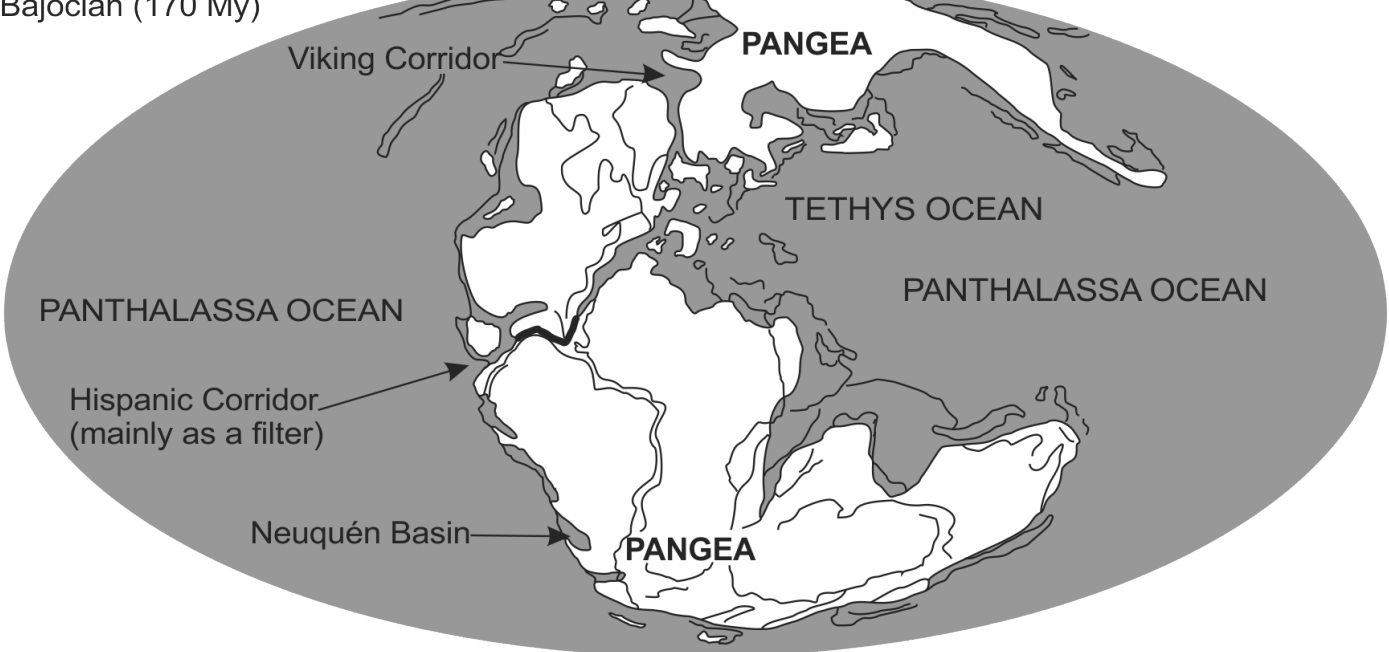

Late Jurassic

Oxfordian (160 My)

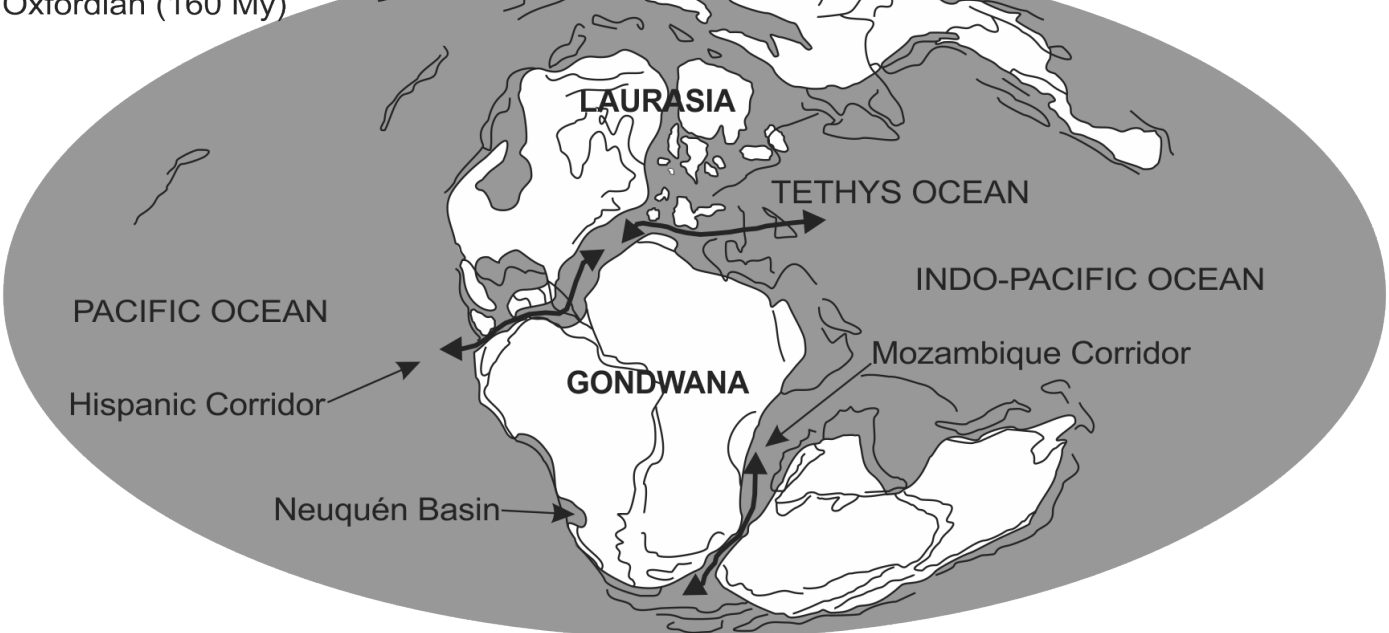

Land

Sea $\square$ System of rift valleys

Figure 3. Paleogeographic maps of the Jurassic world (modified from Iturralde-Vinent, 2006). 
southern Africa with the South Pacific. This seaway became wider towards the Oxfordian, allowing the incoming of the high-latitude bivalve taxa into the East African (Damborenea et al., 2013).

\section{DISTRIBUTION OF ORGANIC-WALLED MARINE MICROPLANKTON FROM THE NEUQUÉN BASIN}

The deposits of the Neuquén Basin are characterized by alternating transgressive marine and regressive non-marine phases. Thus, the stratigraphical record of marine organic-walled microplankton (dinoflagellates, prasinophytes, acritarchs and other algae) is discontinuous (Tab. 1). However, the distribution of mainly dinoflagellate cysts enabled an outline of general paleobiogeographic patterns. The Neuquén Basin has a significantly refined biozonation in terms of resolution based on abundant, diverse and very well preserved ammonite faunas. In this paper, the word "diversity" is used in its original sense to denote the number of species (Rosenzweig, 1995). Riccardi (2008) presented an update of these zonations.

\section{Early Jurassic}

Currently, only five Liassic formations of the Neuquén Basin have provided palynological assemblages: Los Patillos (Álvarez et al., 1994), Piedra Pintada (Stipanicic et al., 1968; Gulisano and Pando, 1981), Sierra Chacaico (Volkheimer, 1973), Los Molles (Weaver, 1931) and Nestares (González Díaz, in Arrondo and Petriella, 1980) (Figs. 1, 2; Tabs. 1, 2).

Volkheimer et al. (1978) studied the lower (continental) and upper (marine) Member of the Los Patos Formation in the northern part of the Neuquén Basin (western slope of Espinacito Range, High Cordillera of San Juan). The upper Member contains ammonites of the Fanninoceras Assemblage Zone (see Riccardi et al., 1990, 2000) (late Pliensbachian) and Tenuicostatum Standard Zone and Dactylioceras hoelderi Assemblage Zone (see Riccardi, 2008) (early Toarcian). The marine elements are represented only by acritarchs (Schizocystia rara Playford and Dettman 1965, Leiosphaeridia sp.) and prasinophytes (Pleurozonaria sp., Cymatiosphaera sp.). After Álvarez et al. (1994) the original Los Patos Formation should be considered a nomen nudum. They proposed that Los Patos should be divided in two units: Rancho de Lata and Los Patillos formations. The levels studied by Volkheimer et al., (1978), under the name upper Member, should now be considered as belonging to the lower section of Los Patillos Formation (Fig. 2).

A marine sequence, belonging to the Piedra Pintada Formation, crops out near Piedra del Aguila (southern border of the Neuquén Basin), which was assigned to the Pliensbachian due to the presence of Austromorphites behrendseni Jaworski (Arguijo et al., 1982; Arguijo and Volkheimer, 1985). The marine components of the recovered palynological association are represented by cf. Granodiscus staplinii (Pocock) Jiabo 1978, Tasmanites suevicus (Eisenack) Wall 1965 and proximate indeterminate dinocysts. The Sierra Chacaico and Los Molles formations from the Sierra de Chacaico area yielded guide ammonites of the Austromorphites behrendseni Assemblage Zone (Hillebrandt, 1987, 2006) (late early Pliensbachian) and Dactylioceras hoelderi Assemblage Zone (see Hillebrandt, 1987; Riccardi et al., 1990, 2000; Hillebrandt et al., 1992) (early Toarcian), respectively (Volkheimer, 1973). The recovered marine palynological assemblages from these units are characterized by acritarchs (Solisphaeridium cf. debilispinum (Wall and Downie) Sarjeant 1973 and Micrhystridium sp.) and prasinophytes (Campenia austroamericana Volkheimer 1974, Lancettopsis sp., Pterospermopsis sp. A, Pterospermopsis sp. B and Tasmanites suevicus) (Volkheimer, 1974).

An Early Jurassic siliciclastic sequence crops out at Alicurá (Limay River) in the southern part of the Neuquén Basin. The marine assemblage recovered from the Las Coloradas Formation (Quartino et al., 1981) was studied by Volkheimer et al. (1981), and assigned to the Pliensbachianearly Toarcian age. This unit is characterized by acritarchs, Hyalinsphaeridia cf. hyalina (Deflandre) Bernier and Courtinat 1979, G. staplinii), Deunffia and Leiofusa. Zavattieri et al. (2008) discussed the stratigraphic position of this unit, which for priority reasons is called the Nestares Formation (Fig. 2). These authors presented an interesting assemblage characterized by marine components, such as the Parvocysta suite, Phallocysta, Nannoceratopsis and Suessiaceae (Figs. 5.15-16) and Callialasporites trilobatus (Balme) Dev 1961 pollen grains, among others, based on a new sampling at the Alicurá Dam. This palynoflora suggests a late Toarcian age; therefore they relocated this unit to the basal part of the Cuyo Group. 
TABLE 1 - Distribution of Jurassic organic-walled marine microplankton species from Neuquén Basin.

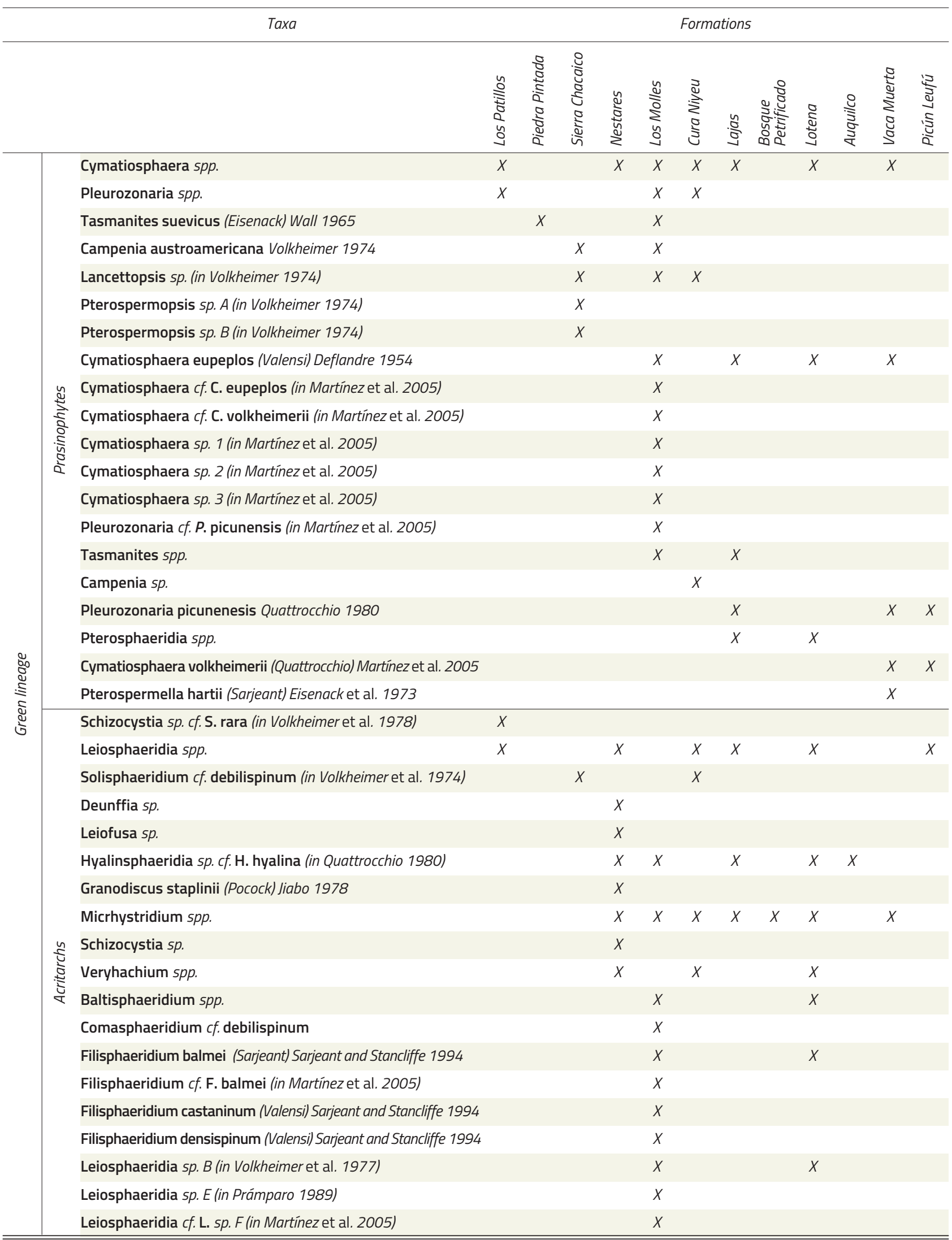




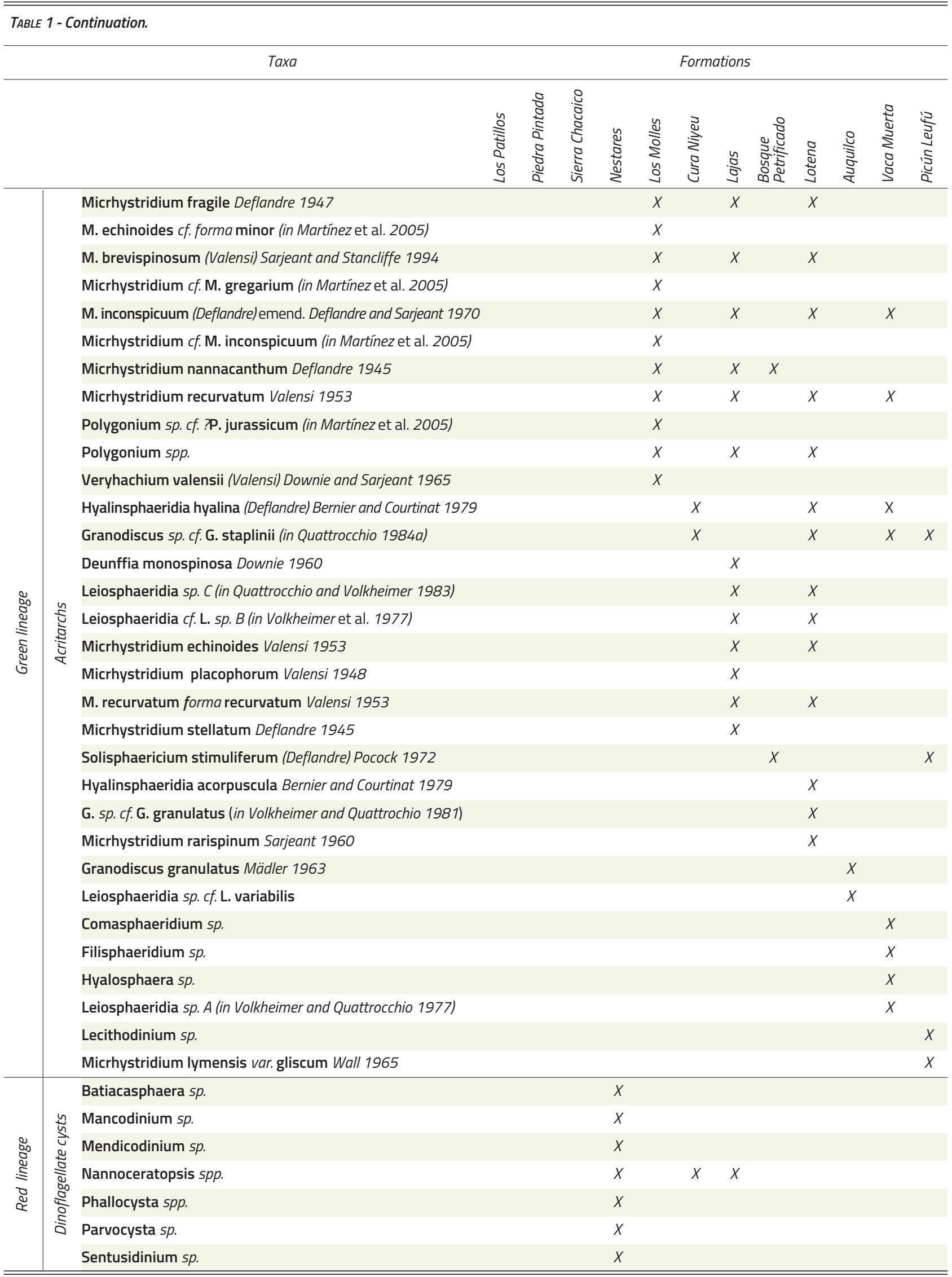


TABLE 1 - Continuation.

\begin{tabular}{|c|c|c|c|c|c|c|c|c|c|c|c|c|c|c|}
\hline & & & 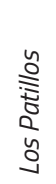 & $\begin{array}{l}\frac{1}{0} \\
\frac{0}{0} \\
:= \\
0 \\
\frac{0}{0} \\
\frac{0}{2}\end{array}$ & 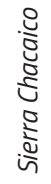 & 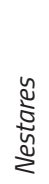 & $\frac{n}{\grave{a}}$ & 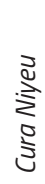 & $\stackrel{n}{g}$ & 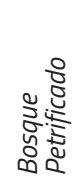 & 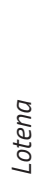 & 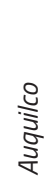 & 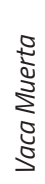 & 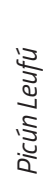 \\
\hline & & Parvocysta $s p$. & & & & $x$ & & & & & & & & \\
\hline & & Sentusidinium $s p$. & & & & $x$ & & & & & & & & \\
\hline & & Cleistosphaeridium sp. & & & & & $x$ & & & & & & & \\
\hline & & Escharisphaeridia pocockii (Sarjeant) Erkmen and Sarjeant 1980 & & & & & $x$ & & $X$ & $x$ & & & $x$ & $x$ \\
\hline & & Gonyaulacysta spp. & & & & & & $x$ & & & $x$ & & & $x$ \\
\hline & & Pareodinia sp. A (in Quattrrocchio 1984a) & & & & & & $x$ & & & & & & \\
\hline & & Rhaetogonyaulacaceae Tipo 1 (in Quattrrocchio 1984a) & & & & & & $x$ & & & & & & \\
\hline & & Rhaetogonyaulacaceae Tipo 2 (in Quattrrocchio 1984a) & & & & & & $x$ & & & & & & \\
\hline & & Rhaetogonyaulax $s p$. & & & & & & $x$ & & & & & & \\
\hline & & Acanthaulax sp. & & & & & & & $x$ & & & & & \\
\hline & & Ctenidodinium spp. & & & & & & & $X$ & & $x$ & & & $x$ \\
\hline & & Dissiliodinium psilatum Prauss 1989 & & & & & & & $x$ & & & & & \\
\hline & & Dissiliodinium cf. baileyi (in Stukins et al. 2013) & & & & & & & $x$ & & & & & \\
\hline & & Dissiliodinium spp. & & & & & & & $x$ & & & & & \\
\hline & & Endoscrinium spp. & & & & & & & $x$ & & $x$ & & & \\
\hline & & Escharisphaeridia spp. & & & & & & & $x$ & & & & & \\
\hline & & Jansonia psilata Martínez et al. 1999 & & & & & & & $x$ & & & & $x$ & \\
\hline & & Kallosphaeridium granulatum (Norvick) Stover and Evitt 1978 & & & & & & & $X$ & & & & & \\
\hline & $\vec{u}$ & Kallosphaeridium spp. & & & & & & & $X$ & & & & & \\
\hline & $=$ & Korystocysta kettonensis (Sarjeant) Woollam 1983 & & & & & & & $x$ & & & & & \\
\hline$\approx$ & $\frac{0}{5}$ & Korystocysta $s p$. & & & & & & & $x$ & & & & & \\
\hline & 言 & Mendicodinium groenlandicum (Pocock and Sarjeant) Davey 1979 & & & & & & & $x$ & & $x$ & & & \\
\hline & & Nannoceratopsis pellucida Deflandre emend. Evitt 1961 & & & & & & & $X$ & & $x$ & & & \\
\hline & & Rhynchodiniopsis cladophora (Deflandre) Below 1981 & & & & & & & $x$ & & $x$ & & & \\
\hline & & Acanthaulax downiei (Sarjeant) Sarjeant 1976 & & & & & & & & & $x$ & & $x$ & \\
\hline & & Ambonosphaera? Staffinensis (Gitmez) Poulsen and Riding 1992 & & & & & & & & & $x$ & & & \\
\hline & & Barbatacysta (f. brevispinosa (in Courtinat and Gaillard 1980) & & & & & & & & & $x$ & & & \\
\hline & & Chytroeisphaeridia chytroeides (Sarjeant) Downie and Sarjeant 1965 & & & & & & & & & $x$ & & & \\
\hline & & Cleistosphaeridium lumectum (Sarjeant) Davey et al. 1969 & & & & & & & & & $x$ & & & \\
\hline & & Diacanthum argentinum Quattrocchio and Sarjeant 1992 & & & & & & & & & $x$ & & & $x$ \\
\hline & & Dissiliodinium volkheimeri Quattrocchio and Sarjeant 1992 & & & & & & & & & $x$ & & & \\
\hline & & Durotrigia $s p$. & & & & & & & & & $x$ & & & \\
\hline & & Ellipsoidictyum gochtii Fensome 1979 & & & & & & & & & $x$ & & & \\
\hline & & Endoscrinium galeritum subsp. reticulatum Klement 1960 & & & & & & & & & $x$ & & & \\
\hline & & E. cf. E. g. subsp. reticulatum (in Riding et al. 2011) & & & & & & & & & $x$ & & & \\
\hline & & Gonyaulacysta jurassica (Deflandre) Norris and Sarjeant 1965 & & & & & & & & & $x$ & & $x$ & \\
\hline & & Gonyaulacysta jurassica subsp. adecta (Deflandre) Sarjeant 1982 & & & & & & & & & $x$ & & & \\
\hline & & Hystrichosphaeridium sp. A (in Volkheimer and Quattrochio 1981) & & & & & & & & & $x$ & & & \\
\hline & & Liesbergia liesbergensis Berger 1986 & & & & & & & & & $x$ & & & \\
\hline
\end{tabular}




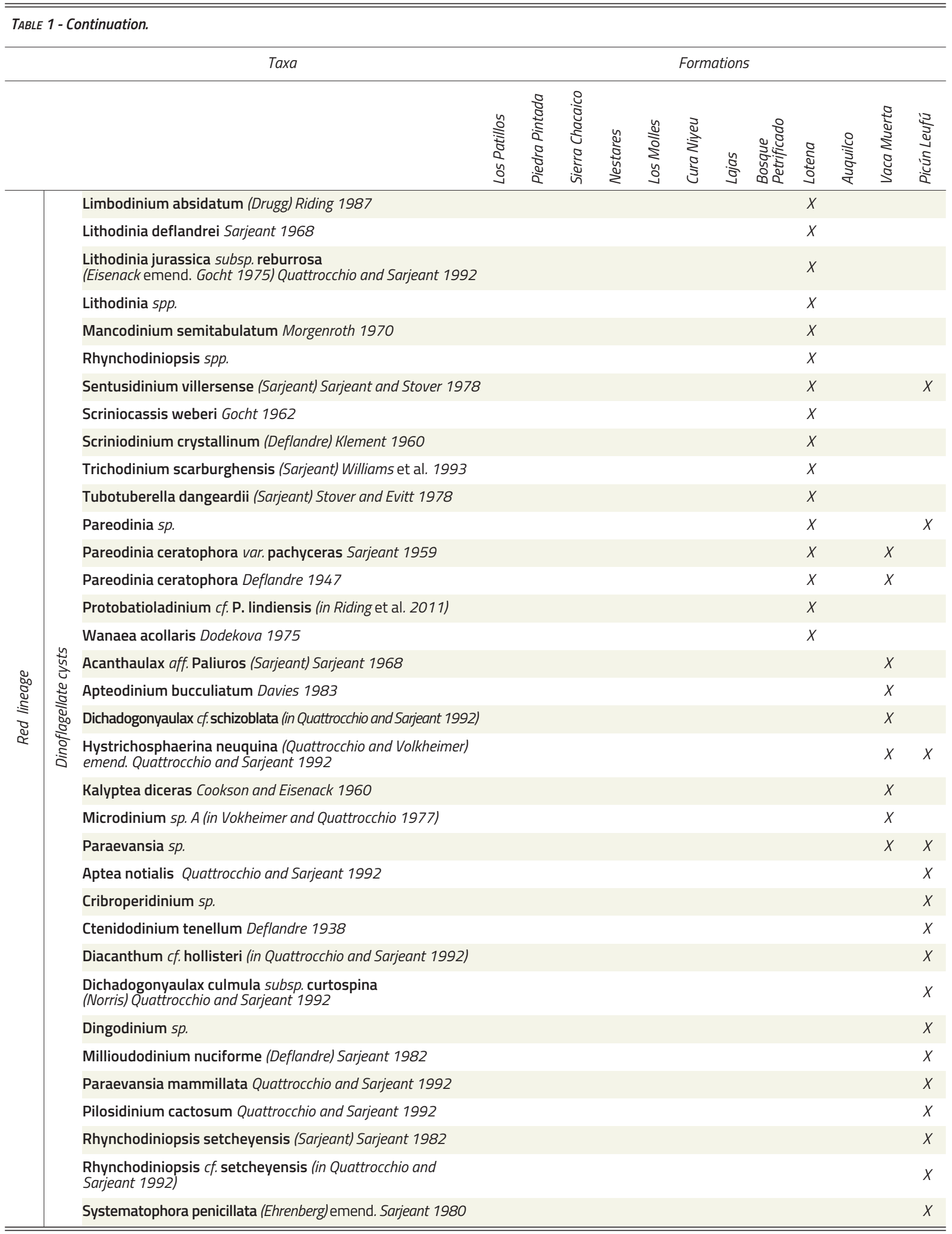


TABLE 2 - Middle Jurassic localities considered in this study (the age of the units is based on paleontological contributions, main ammonoids and palynomorphs data, carried out by different authors and it does not represent the entire age range of each unit).

\begin{tabular}{|c|c|c|c|}
\hline Formation & Age & Localities & Contributions \\
\hline Picún Leufú & late middle Tithonian-early Berriasian & Picún Leufú Creek & 17 \\
\hline Vaca Muerta (partially) & $\begin{array}{l}\text { early-middle Tithonian } \\
\text { early Tithonian }\end{array}$ & $\begin{array}{c}P P L \\
\text { Caichigüe }\end{array}$ & $14,17,18,26,27$ \\
\hline Auquilco & late Oxfordian & $P C$ & 25 \\
\hline Lotena & $\begin{array}{c}\text { late Callovian } \\
\text { middle-late Callovian }\end{array}$ & $\begin{array}{c}\text { Portada Covunco }(P C) \\
\text { Puente Picún Leufú (PPL) }\end{array}$ & $\begin{array}{c}9,19 \\
17,19,28\end{array}$ \\
\hline Bosque Petrificado & Callovian & Quebrada del Sapo & 12 \\
\hline Lajas & $\begin{array}{c}\text { Middle Jurassic } \\
\text { late Aalenian/early Bajocian-early Callovian }\end{array}$ & $\begin{array}{c}M, C h \\
\text { Sierra de Chacaico } \\
L M, P P L, P C \text {, Puesto Bascuñán, CC }\end{array}$ & $\begin{array}{c}5,20 \\
21,22,23 \\
3,4,8,10,11\end{array}$ \\
\hline Cura Niyeu & early-middle Bajocian & $\begin{array}{c}L M \\
\text { Cura Niyeu }\end{array}$ & $\begin{array}{l}15,16 \\
6,7\end{array}$ \\
\hline Los Molles & $\begin{array}{l}\text { early Bajocian } \\
\text { late Aalenian-early Bajocian }\end{array}$ & $\begin{array}{c}\text { Charahuilla (Ch) } \\
\text { Lohan Mahuida (LM), Los Molles (M), Co. Lotena, PPL, } \\
\text { Puesto Policía, Co. Chacaico (CC) }\end{array}$ & $\begin{array}{c}5 \\
3,8,12,13\end{array}$ \\
\hline & early Toarcian & Sierra de Chacaico & 24 \\
\hline Nestares & late Toarcian & Alicurá Dam & 30,31 \\
\hline Sierra Chacaico & late Early Pliensbachian & Sierra de Chacaico & 24 \\
\hline Piedra Pintada & Pliensbachian & Piedra del Aguila & 1,2 \\
\hline Los Patillos & late Pliensbachian-early Toarcian & Arroyo de Los Patillos & 29 \\
\hline \multicolumn{4}{|c|}{$\begin{array}{l}\text { 1, Arguijo and Volkheimer, (1985); 2, Arguijo et al. (1982); 3, García, (1998); 4, García et al. (1994); 5, García et al. (2006); 6, González-Amicón and } \\
\text { Volkheimer, (1982a); 7, González-Amicón and Volkheimer, (1982b); 8, Martínez, (1999); 9, Martínez and Quattrocchio, (2004); 10, Martínez et al. (1999); } \\
\text { 11, Martinez et al. (2001); 12, Martínez et al, (2005); 13, Martinez et al. (2008); 14, Quattrocchio, (1980); 15, Quattrocchio, (1984a); 16, Quattrocchio, } \\
\text { (1984b); 17, Quattrocchio and Sarjeant, (1992); 18, Quattrocchio and Volkheimer, (1990); 19, Riding et al. (2011); 20, Scafati and Morbelli, (1984); } \\
\text { 21, Stukins, (2011); 22, Stukins et al. (2013a); 23, Stukins et al. (2013b); 24, Volkheimer, (1973); 25, Volkheimer and Moroni, (1981); 26, Volkheimer and } \\
\text { Quattrocchio, (1975); 27, Volkheimer and Quattrocchio, (1977); 28, Volkheimer and Quattrocchio, (1981); 29, Volkheimer et al. (1978); 30, Volkheimer } \\
\text { et al. (1981); 31, Zavattieri et al. (2008). }\end{array}$} \\
\hline
\end{tabular}

As pointed out above, during Early Jurassic times the organic-walled marine microplankton assemblages were very scarce and of low diversity in the Neuquén Basin. Mainly acritarchs and prasinophytes have been identified. The first diversified dinoflagellate cyst recorded in the South American late Early Jurassic was found in the late Toarcian Nestares Formation (Zavattieri et al., 2008).

\section{Middle Jurassic}

The palynology of Middle Jurassic deposits of the Neuquén Basin has been widely studied during the last five decades. Several formations have provided well preserved continental and marine palynofloras (Figs. 1, 2; Tabs. 1-2). The Middle Jurassic units of the Cuyo Group represent the first effective oceanic incursion into the Neuquén Embayment. These paleoenvironmental conditions led to more relatively abundant and diversified microplanktonic marine assemblages than the Liassic associations. The majority of the analyzed formations represent marginal marine environments, yielding marine assemblages mainly dominated by acritarchs (Micrhystridium and Veryhachium complexes) and prasinophytes (e.g., Cymatiosphaera, Pleurozonaria and Tasmanites).

The Los Molles Formation, in west-central Argentina, 
was carefully calibrated through the ammonite zonation. Zavala (1996b) reported the presence of ammonite fauna belonging to the Malarguensis Standard Zone, Singularis Standard Zone, and Giebeli Standard Zone, which suggests a late Aalenian-early Bajocian age. The marine components of the palynoflora from this formation are characterized by acritarchs (mainly Acanthomorphitae) and prasinophytes; dinocysts are scarce, Escharisphaeridia pocockii (Sarjeant) Erkmen and Sarjeant, 1980 (Fig. 5.19) and Cleistosphaeridium sp. These assemblages are in agreement with a marginalmarine environment with sub-normal salinity (Martínez et al., 2008).

The stratigraphic position of the Lajas Formation is given by ammonite data. The presence of Singularis Standard Zone, Giebeli Standard Zone, Humphriesianum Standard Chronozone, Rotundum Standard Chronozone, and Vergarensis Standard Zone suggests an early Bajocian-early Callovian age (Zavala, 1996b, Quattrocchio et al., 2007). This coincides with the age proposed by Stukins et al. (2013a), based on dinoflagellate cyst assemblages. The Lajas dinocyst assemblages are scarce, predominating proximate forms (Escharisphaeridia pocockii), species indicative of euhryaline conditions (Nannoceratopsis pellucida Deflandre emend. Evitt, 1961) and opportunistic taxa, Jansonia psilata Martínez et al., 1999 (Figs. 5.17-18), (Martínez et al., 1999; Martínez and Quattrocchio, 2005). Stukins (2011) and Stukins et al. $(2013 a, b)$ reported an early Bajocian assemblage containing Dissiliodinium psilatum Prauss 1989 and Korystocysta kettonensis (Sarjeant) Woollam 1983 at Sierra de Chacaico. In the uppermost part of the Lajas Formation, in Portada Covunco, these authors mentioned the presence of Rhynchodiniopsis cladophora (Deflandre) Below 1981 in association with Mendicodinium groenlandicum (Pocock and Sarjeant) Davey 1979 suggesting an early Callovian age.

Cura Niyeu (at Lohan Mahuida) and Lotena formations yielded diversified and abundant dinocyst assemblages. The Cura Niyeu Formation contains ammonite faunas including lower Bajocian Sonninia cf. zitteli and S. espinazitensis and middle Bajocian Chondroceras submicrostomum and Otoites sp. (Quattrocchio, 1984a). The marine assemblage is mainly composed of acavate forms, such as rhaetogonyaulacoid cysts and Nannoceratopsis species (Quattrocchio and Volkheimer, 1990) (Tab. 1).
Lotena palynological marine associations have been recovered from Puente Picún Leufú and Portada Covunco (Quattrocchio and Sarjeant, 1992; Martínez and Quattrocchio, 2004). These sediments are considered as midlate Callovian in age (Groeber et al., 1953; Stipanicic, 1969; Riccardi et al., 1990; Riccardi 2008) on account of the ammonite identified in the former locality, Rehmannia (Loczyceras) patagoniensis (Dellapé et al., 1979). The Lotena Formation at the Portada Covunco section lacks ammonite faunas, however the underlying Lajas Formation yielded Eurycephalites cf. vergarensis, which is characteristic of the Vergarensis Chronozone, and suggests an early Callovian age (Riccardi et al., 1989, 1990; Riccardi, 2008). The organicwalled marine microplankton of this unit is characterized by the appearance of chorate cysts (Quattrocchio and Volkheimer, 1990; Quattrocchio and Sarjeant, 1992). Riding et al. (2011) restudied the palynological samples of the localities mentioned above, and refined the biostratigraphy based on the dinocyst assemblages. These authors suggested a late Callovian age taking into account the first appearance of Limbodinium absidatum (Drugg) Riding 1987, Wanaea acollaris Dodekova 1975, and Scriniodinium crystallinum (Deflandre) Klement 1960.

The Bosque Petrificado Formation (Zavala and Freije, 2002 = "Challacó" Formation of Zavala and González, 2001) lacks ammonite control; however, it has been correlated with the basal part of the Lotena Formation. Thus, a Callovian age was suggested for these strata (Zavala and Freije, 2002), which was later confirmed by palynological studies (Martínez et al., 2005). At the Quebrada del Sapo section this unit yielded a marginal marine assemblage characterized by Escharisphaeridia pocockii and Micrhystridium complex (Martínez et al., 2005).

\section{Late Jurassic}

Four units provided well preserved continental and marine palynofloras: Lotena, Auquilco, Vaca Muerta and Picún Leufú formations. However, the most diversified dinocyst assemblages were found in the Vaca Muerta and Picún Leufú formations (Figs. 1, 2; Tabs. 1-2).

Olivera et al. (2010) suggested marginal marine conditions at least until the latest Oxfordian-early Kimmeridgian for the Lotena Formation at Picún Leufú sub-basin (Barda 
Norte locality), based on the presence of organic-walled marine microplankton and foraminifers.

The Auquilco Formation at Portada Covunco, late Oxfordian in age (Volkheimer and Moroni, 1981) bears a well preserved palynoflora deposited in a near shore marine environment. The microplankton is scarce and of low diversity, exclusively represented by acritarchs Sphaeromorphitae ( $G$. granulatus, Leiosphaeridia sp. cf. L. variabilis, Hyalinsphaeridia cf. hyalina) and Acanthomorphitae (cf. Baltisphaeridium sp.).

The Vaca Muerta Formation has already been studied palynologically at Caichigüe and Puente Picún Leufú (Volkheimer and Quattrocchio, 1975, 1977; Quattrocchio, 1980; Quattrocchio and Volkheimer, 1990; Quattrocchio and Sarjeant, 1992). Fragmentary ammonites assigned to Virgatosphinctes sp. found in the Caichigüe area, together with correlation with the fossiliferous beds of the near locality of Charahuilla, suggest an early Tithonian age (Volkheimer and Quattrocchio, 1975). The marine association recovered from these sediments is widely dominated by acritarchs and prasinophytes, whereas dinocysts are very scarce (Volkheimer and Quattrocchio, 1977).

The lower part of the Vaca Muerta Formation sequence at Puente Picún Leufú yielded ammonites, including Choicensisphinctes choicensis (Burckhardt) and Torquatisphinctes sp. belonging to the Virgatosphinctes mendozanus Zone (Burckhardt 1900) of the latest early to middle Tithonian (Riccardi, 2008). This formation includes younger strata towards the centre of the Neuquén Basin (Leanza in Quattrocchio and Sarjeant, 1992). The organic-walled marine microplankton from the middle part of the Vaca Muerta Formation at the Puente Picún Leufú section shows similar proportions of dinocysts and acritarchs/prasinophytes suggesting a shallow marine environment (Quattrocchio and Sarjeant, 1992).

At the southeastern margin of the basin, the Vaca Muerta Formation is overlain by the shallow marine carbonates and siliciclastic sediments of the Picún Leufú Formation. A few ammonite levels yielding Subdichotomoceras, Lytohoplites, Corongoceras and Substeueroceras in the type locality, Picún Leufú Creek, suggest these sediments range between late middle Tithonian and early Berriasian in age (Armella et al., 2007). The Picún Leufú Formation shows an increase in dinocyst diversity when compared with the
Vaca Muerta Formation. Moreover, several endemic taxa, such as Aptea notialis, Diacanthum argentinum, Paraevansia mammillata and Pilosidinium cactosum, were defined in this formation by Quattrocchio and Sarjeant (1992).

\section{DISCUSSION}

At the global scale several authors have recognized the presence of two realms (Boreal and Tethyan) during the Early Jurassic, based on different ammonite, foraminiferal, brachiopod and calcareous nannofossil assemblages (in Bucefallo Palliani and Riding, 1999). From a palynological point of view, many diversified Early Jurassic dinocyst assemblages have been reported from these faunal provinces, mainly from the Northern Hemisphere. Some of these citations include Dapcodinium from the Hettangian stage and Liasidinium from the late Sinemurian in southwestern Germany (in Zavattieri et al., 2008), Luehndea, Mancodinium, Mendicodinium, Nannoceratopsis, Scrinocassis, among others, from the Pliensbachian and Toarcian of many European localities (in Bucefallo Palliani and Riding, 1999), and the Parvocysta suite, including Phallocysta, throughout the late Toarcian of northern East Siberia (Riding et al., 1999). These authors postulated that a mutual exchange of taxa occurred between the Boreal and Tethyan realms since the Pliensbachian. These migrations were possible due to the opening of an epicontinental passageway between Greenland and Norway named Viking Corridor (Fig. 3). Even though it is true that the dinocyst assemblage from the Nestares Formation shares more components, at a genus level, with northern East Siberian than with north-western Australian (Riding and Helby, 2001) assemblages, it is quite different from both assemblages. The reason the southern Neuquén Basin (Alicurá Dam) assemblages are unlike any other late Toarcian dinocyst associations may probably be due to the paralic bay depositional setting of the Nestares Formation.

A plausible migration route of this marine biota might have been the Trans-Pacific route of Aberhan (2001) because the Hispanic Corridor mainly acted as a filter at this time; a latitudinal exchange surrounding Pangea would not be expected due to the presence of the Jurassic climatic zones proposed by Parrish (1992). Moreover, the absence of an active subduction zone immediately to the west of South America at this time would have allowed the trans- 
pacific interchange (Howell et al., 2005) (Fig. 3).

In summary, the scarcity of dinoflagellate cysts during the Early Jurassic in the Neuquén Basin was probably related to the paleogeographic configuration of the basin. During the earlier Jurassic Pre-Cuyo Group the paleogeography showed the dominance of isolated rift depocenters (Vergani et al., 1995; Howell et al., 2005). This context partially remained for the lower Cuyo Group deposits. The interconnection among the different depocenters would have been scarce with the development of relatively small basins with variable salinity and low oxygenated water conditions. This environment was highly unsuitable for the proliferation of cyst-forming dinoflagellates (van de Schootbrugge et al., 2005 and references therein). Thus, these eco- logical niches were colonized by green algae, including prasinophytes and acritarchs (Figs. 4, 5.1-14).

Since the late Toarcian, the isolated rift depocenters of earlier Jurassic times were gradually amalgamated into a single, broad basin. These paleoenvironmental conditions continued until the Early Cretaceous (Vergani et al., 1995). The presence of this single basin allowed the development of relatively more diversified organic-walled marine microplankton assemblages (i.e., acritarchs, prasinophytes and dinocysts) during the Middle Jurassic. The marine palynofloras were mainly dominated by acritarchs and prasinophytes during the Aalenian-early Callovian (Cuyo Group) when the marginal condition prevailed in the marine environment. The most diversified Jurassic dinocyst assem-

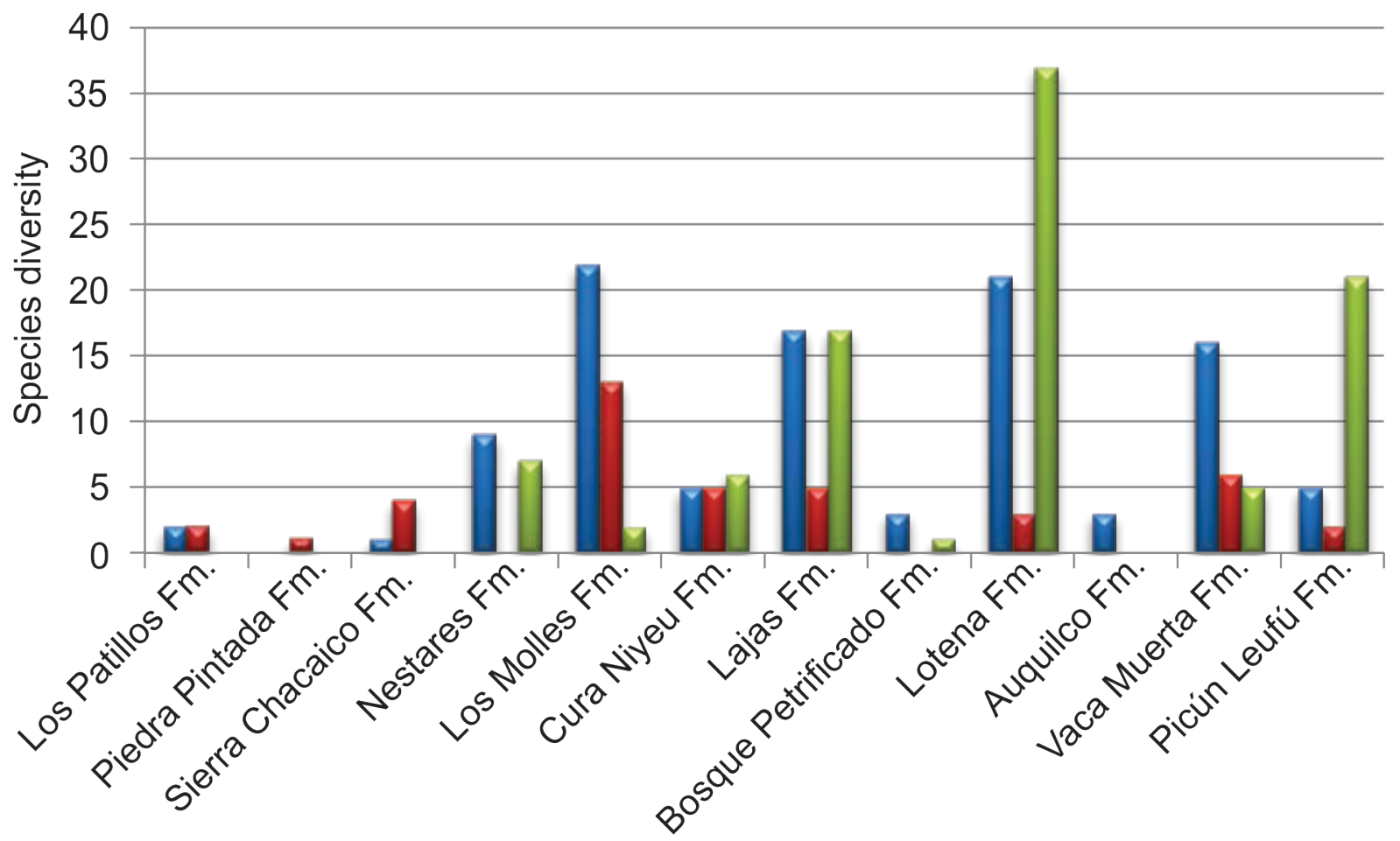

Acritarhs

Drasinophytes

$\square$ Dinocysts

Figure 4. Histogram showing the distribution of the organic-walled marine microplankton (acritarchs, prasinophytes and dinocysts) from the units considered in this study. 
blages have been reported from the late Callovian Lotena Formation which suggests the predominance of nonrestricted open marine conditions in the Neuquén Basin at that time (Figs. 4, 5.20-26, 6.1-9; Tab. 1). A similar increase in dinoflagellate cyst diversity was reported for the late Callovian sequences of Europe (Riding et al., 2010). The main affinity of the Lotena dinocyst association was inferred as European, suggesting a free movement via the Hispanic seaway (Riding et al., 2011) which is reinforced by the presence of some cosmopolitan forms, such as Gonyaulacysta jurassica (Deflandre) Norris and Sarjeant 1965 and Scriniodinium crystallinum, in this palynoflora (Martínez and Quattrocchio, 2004). However, the presence of Dissiliodinium volkheimeri Quattrocchio and Sarjeant 1992 (Fig. 5. 26) a taxon confined to the Southern Hemisphere (Riding et al., 2011) is worth noting. Mantle (2009) reported its first worldwide occurrence from the northern Bonaparte Basin, Timor Sea (Australia), from the Wanaea indotata Interval Zone (middle Bathonian-early Callovian) through the Voodooia tabulata Interval Zone (late Callovian). Thus, a connection from northern Australasia to the Neuquén Basin via the Mozambique Corridor cannot be entirely ruled out.

The next widespread Paleopacific marine transgression in the Neuquén Basin consists of bituminous shales, marls and limestones of the Vaca Muerta Formation (Legarreta and Uliana, 1991, 1996). There is a decrease in dinocyst diversity and an increase in the acritarchs and prasinophyte content in the Vaca Muerta Formation compared with the Lotena Formation (Quattrocchio, 1980; Quattrocchio and
Volkheimer, 1990; Quattrocchio and Sarjeant, 1992), which may be related to the anoxic to dysoxic environmental condition that prevailed during the deposition of the Vaca Muerta Formation (Figs. 4, 6.15-16.18 Tab. 1). Studies on modern dinoflagellates have shown that oxygen availability exerts a strong control on cyst germination, with anaerobic conditions completely inhibiting the excystment of most taxa (Candel et al., 2013 and references therein).

It may be argued that oxygen availability is one of the most important factors in controlling the diversity and abundance of benthic biota. The relative increase in dinocyst diversity in the Picún Leufú assemblages might be correlated with a more oxygenated condition of the water column at that time, compared with the underlying formation (Figs. 4, 6.10-14.17; Tab. 1).

The distribution of the cosmopolitan and endemic taxa is influenced by the ecology of the environment (Valentine, 1973). The Picún Leufú Formation was deposited during a highstand system tract and comprises a wide range of subenvironments within the whole marginal marine system (Armella et al., 2007). As mentioned by Götz et al. (2005) during the highstand phase, the environmental conditions stabilize and the biota becomes more diverse, therefore the main mechanism of this enrichment is speciation of endemic taxa. This context highly correlates with the presence of several endemic species recorded in the Picún Leufú strata.

Figure 5. 1-2, Michrystridium brevispinosum; 1, UNSP LM 1312 (from Martínez et al., 2001); 2, UNSP BN 1957c (from Olivera et al., 2010); 34, Michrystridium recurvatum forma recurvatum; 3, UNSP LM 1312 (from Martínez et al., 2001); 4, UNSP BN 1957c (from Olivera et al., 2010); 5, Michrystridium fragile, UNSP LM 1312; 6, Michrystridium inconspicuum, UNSP LM 1312; 7, Michrystridium placophorum UNSP LM 1312; 8, Michrystridium echinoides UNSP LM 1312 (5-8, from Martínez et al., 2001); 9, Baltisphaeridium sp., UNSP LM 1312f, Efco: R43/4; 10, Polygonium sp., UNSP LM 1312 (from Martínez et al., 2001); 11, Tasmanites sp., UNSP PL 1429a; 12, Pleurozonaria cf. P. picunensis, UNSP PL 1429CAN; 13, Cymatiosphaera sp. 2, UNSP PL 1466a; 14, Cymatiosphaera cf. C. volkheimerii, UNSP PL 1429CAN (11-14, from Martínez et al., 2005); 15, ?Suessiaceae indet. MPLP 7235E; 16, Parvocysta sp. MPLP 7187A (15-16, from Zavattieri et al., 2008); 17-18, Jansonia psilata, UNSP LM 1312 (from Martínez et al., 1999); 19, Escharisphaeridia pocockii, UNSP PL 1429c (from Martínez et al., 2005); 20, Chytroeisphaeridia chytroeides, UNSP PC 1525d, Efco: 022/1; 21, Wanaea acollaris, UNSP PL 2971/2 (from Riding et al., 2011); 22, Ambonosphaera? staffinensis UNSP PL 2970/8, EFco: H39; 23, Lithodinia jurassica subsp. reburrosa UNSP PL 2970 (from Quattrocchio and Sarjeant, 1992); 24, Limbodinium absidatum, UNSP PL 2971/7 (from Riding et al., 2011); 25, Mendicodinium groenlandicum, UNSP PL 2971/7, EFco: E39/1; 26, Dissiliodinium volkheimeri UNSP PL 2970 (from Quattrocchio and Sarjeant, 1992). Scale bar=10 $\mu \mathrm{m}$. Acronyms: UNSP (Universidad Nacional del Sur, Palinología); MPLP (Mendoza-Paleopalinoteca-Laboratorio de Palinología). 

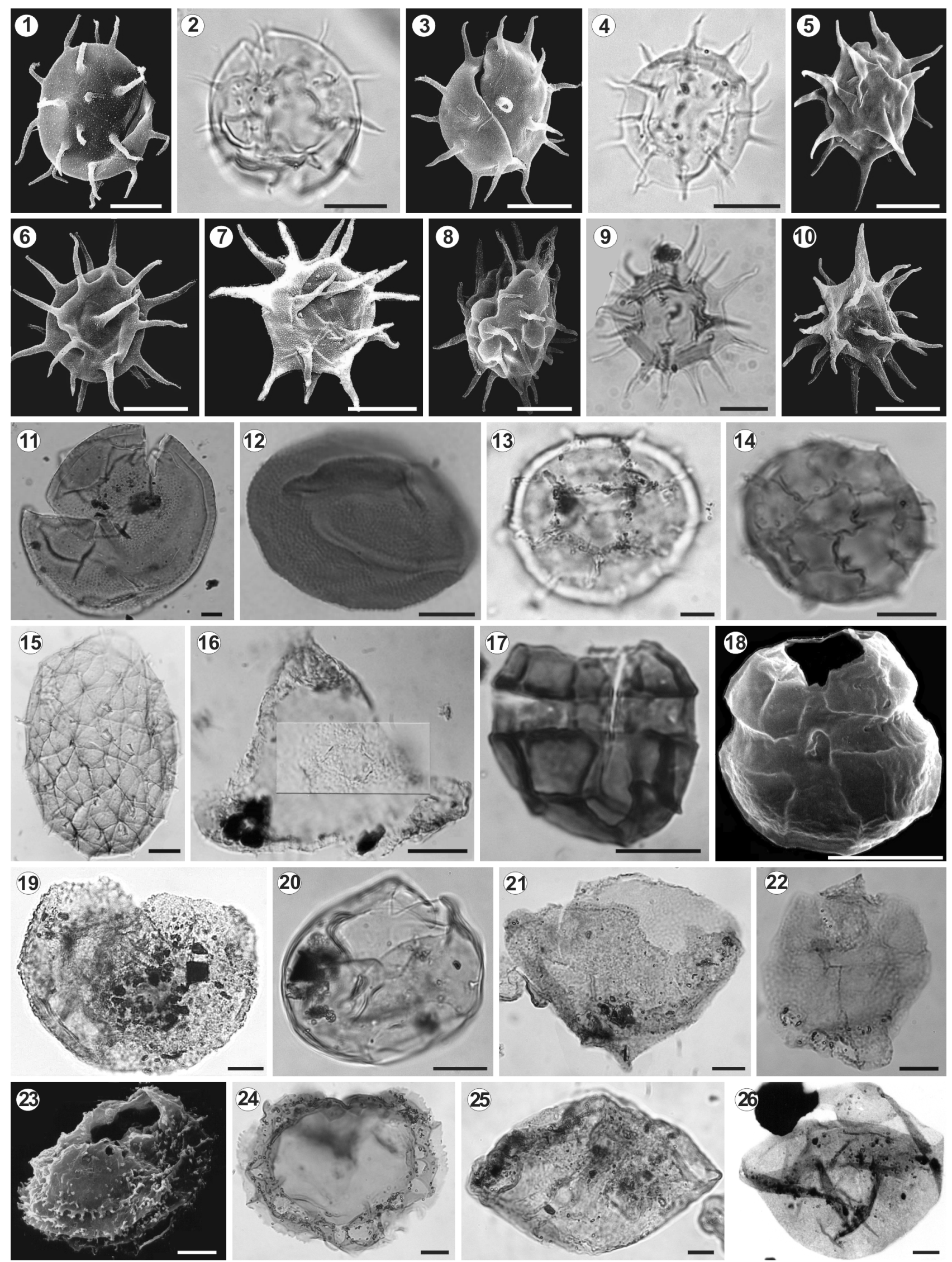

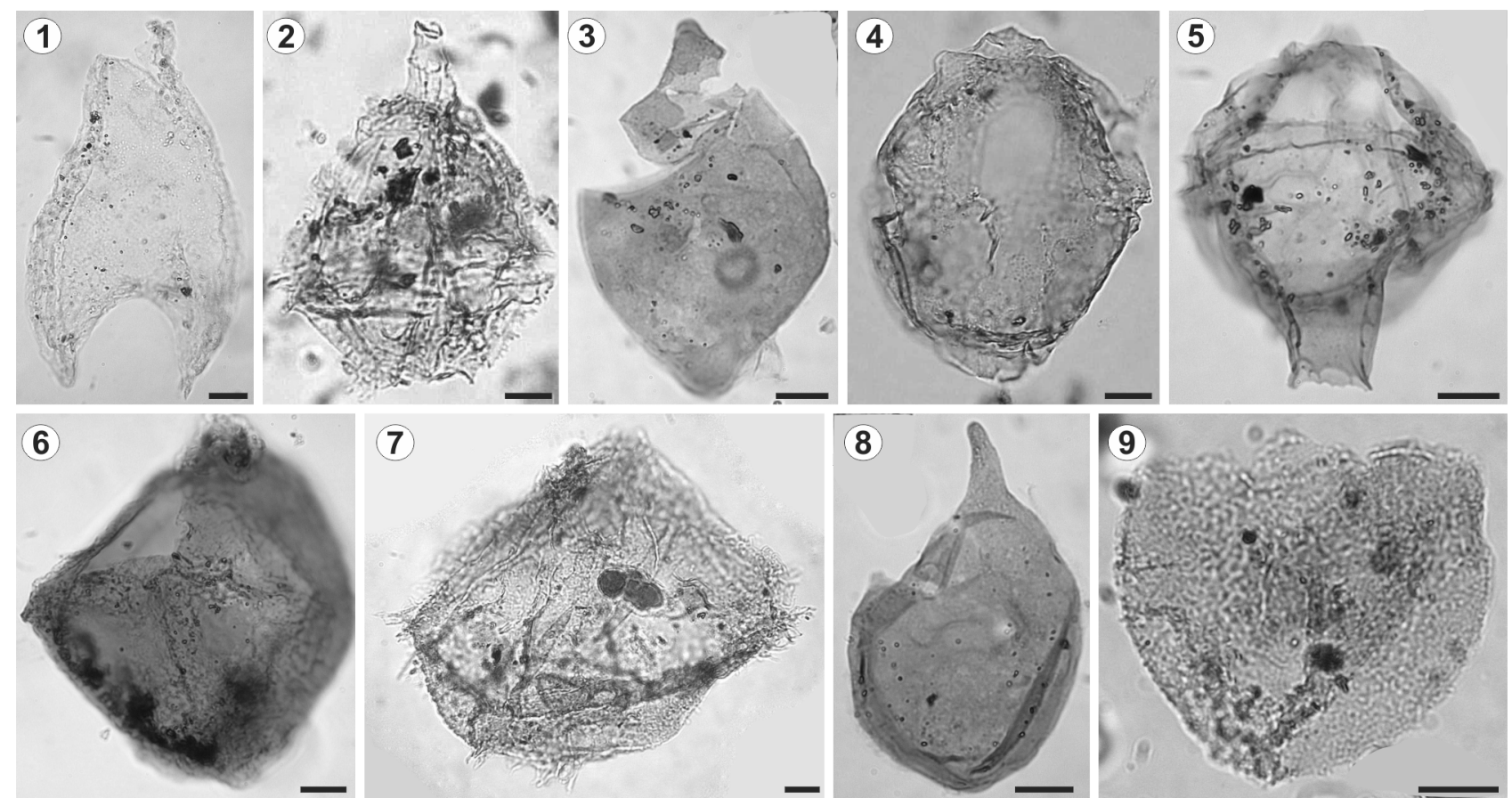
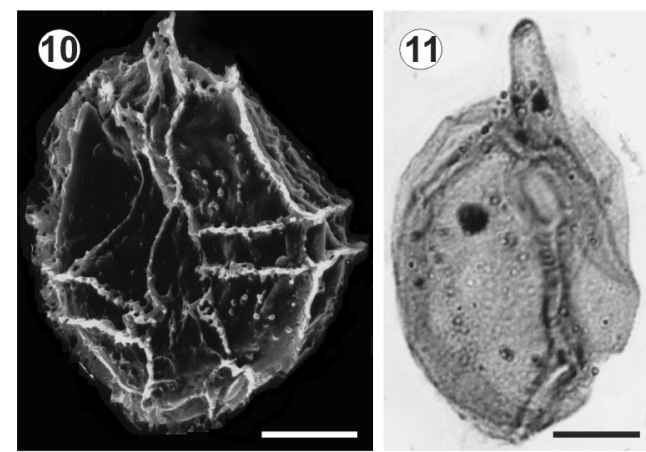
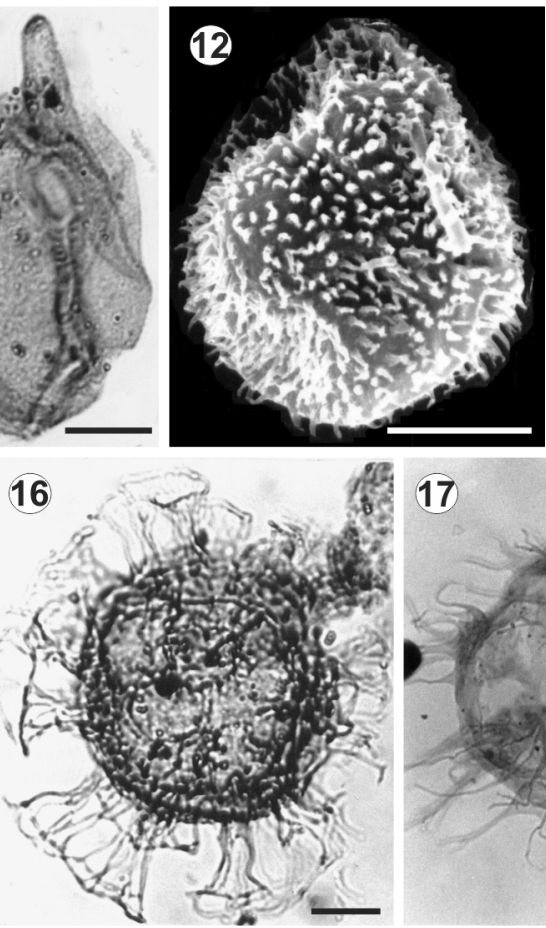

17
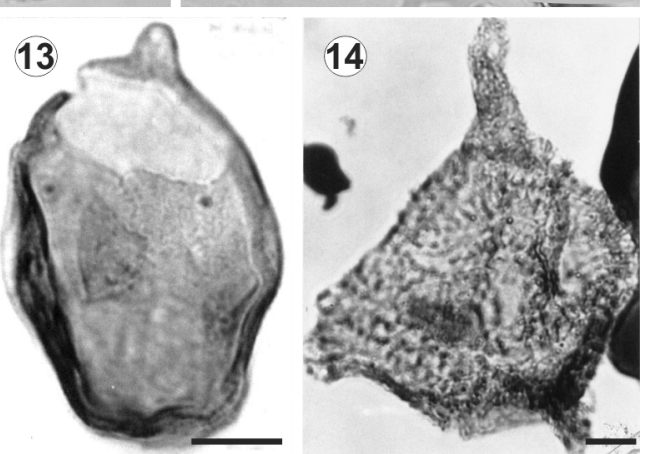

15
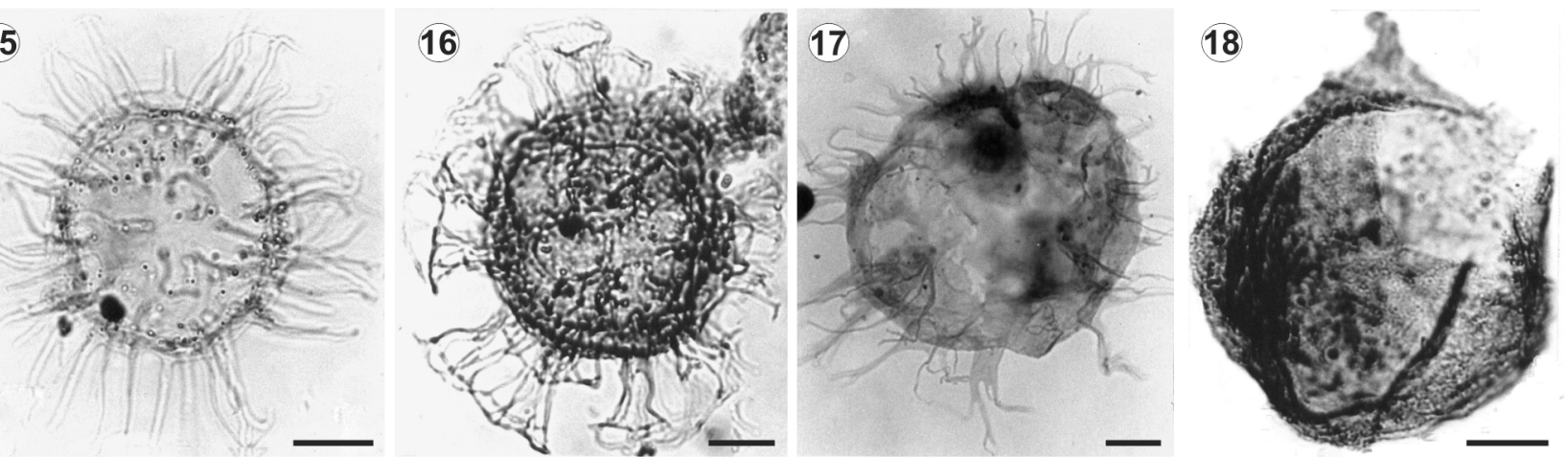

Figure 6. 1, Nannoceratopsis pellucida, UNSP PL 2971/3 (from Riding et al., 2011); 2, Gonyaulacysta jurassica subsp. adecta, UNSP PC 1525b (from Martínez and Quattrocchio, 2004); 3, Protobatioladinium cf. P. lindiensis, UNSP PL 2971/3 (from Riding et al., 2011); 4, Scriniodinium crystaIlinum, UNSP PC 1525c (from Martínez and Quattrocchio, 2004); 5, Tubotuberella dangeardii, UNSP PL 2971/7; 6, Endoscrinium cf. E. galeritum subsp. reticulatum, UNSP PL 2971/7; 7, Rynchodiniopsis cladophora, UNSP PC 1525d; 8, Pareodinia ceratophora, UNSP PL 2971/4 (5-8, from Riding et al., 2011); 9, Lithodinia deflandrei, UNSP BN 1959c (from Olivera et al., 2010); 10, Rhynchodiniopsis cf. setcheyensis, UNSP PL 2966; 11, Pareodinia ceratophora var. pachyceras, UNSP PL 2965/1; 12, Pilosidinium cactosum, UNSP PL 2966; 13, Paraevansia mammillata, UNSP PL 2967/2; 14, Aptea notialis, UNSP PL 2966/2; 15, Cleistosphaeridium lumectum, UNSP PL 2970/4; 16, Hystrichosphaerina neuquina, UNSP PL 2965/6A; 17, Systematophora pinicillata, UNSP PL 2966/1; 18, Milloudodinium nuciforme UNSP PL 2969/4 (10-18, from Quattrocchio and Sarjeant, 1992). Scale bar $=10 \mu \mathrm{m}$. 


\section{CONCLUSIONS}

This paper summarizes all available marine palynological information from the Jurassic units of the Neuquén Basin and constitutes our state of the art view of this topic.

The distribution of the Jurassic organic-walled marine microplankton of the Neuquén Basin is closely related to the paleoenvironmental conditions and the configuration of the basin, as well as to the global and local ocean circulation patterns.

The Early Jurassic units are highly dominated by green algae, including prasinophytes and acritarchs, with very scarce dinoflagellate cysts. This kind of marine palynoflora could correspond to the configuration of the basin which was characterized by different depocenters with scarce interconnections. The Nestares Formation is the only exception with a relatively diversified dinocyst assemblage. A possible migration route of the cosmopolitan marine biota recovered from this unit might have been the Trans-Pacific route, due to the Hispanic Corridor which mainly acted as a filter at that time.

The diversification of the organic-walled marine microplankton recorded in Middle Jurassic units could be the result of the fusion of the Early Jurassic rift depocenters into a single late Toarcian basin, increasing the number of niches available for colonization.

During the Middle Jurassic, two main pulses of marine microplankton diversification can be recognized. In the first one (Aalenian-early Callovian), the assemblages were mainly dominated by acritarchs and prasinophytes. These palynofloras were recovered from the marginal-marine Cuyo Group deposits. The second great episode of flooding in the basin marks the beginning of the second pulse, when more open-marine conditions were established. In this context, the late Callovian Lotena assemblages exhibit the highest dinoflagellate cyst diversity of all the Jurassic units. Two possible migration routes can be recognized for the main biota interchange: the Hispanic Corridor seaway, due to the European affinity of the associations, and the Mozambique Corridor, due to the record of Dissiliodinium volkheimeri that was only recognized in both the Bonaparte (Australia) and Neuquén (Argentina) basins, suggesting a possible Australian connection.

The diversity of the Late Jurassic dinocyst assemblages shows a decrease in regard to the older Lotena assemblages. The anoxic to dysoxic environmental conditions that prevailed during the deposition of the Vaca Muerta Formation controlled the composition of the organic-walled marine microplankton assemblages, dominated by acritarchs and prasinophytes. On the other hand, the relative increase in dinocyst diversity of the Picún Leufú assemblages could be related to well-oxygenated and well-mixed bottom waters.

\section{ACKNOWLEDGMENTS}

This contribution is dedicated to a great leader of the palynology of South America, Prof. Dr. Mirta Quattrocchio, considered as our scientific mother and a very special human being. Mirta was a pioneer in the field of stratigraphy and palynology with special emphasis in the organic-walled marine microplankton. We are grateful to Mercedes Prámparo, an anonymous reviewer and the Section Editor, for their comments that greatly improved the quality of this paper. The authors kindly acknowledge José Di Genio and Elina Cornou for their help with graphics. Finally, we want to thank Mirta for her constant support in our professional and personal lives. This research was supported by CONICET and SeGCYT.

\section{REFERENCES}

Abdelhady, A.A., and Fürsich, F.T. 2015. Palaeobiogeography of the Bajocian-Oxfordian macrofauna of Gebel Maghara (North Sinai, Egypt): Implications for eustacy and basin topography. Palaeogeography, Palaeoclimatology, Palaeoecology 417: 261-273.

Aberhan, M. 2001. Bivalve palaeobiogeography and the Hispanic Corridor: time of opening and effectiveness of a proto-Atlantic seaway. Palaeogeography, Palaeoclimatology, Palaeoecology 165 : 375-394.

Álvarez, P.P. 1996. Los depósitos triásicos y jurásicos de la Alta Cordillera de San Juan. In: V.A. Ramos, M.B. Aguirre-Urreta, P.P. Alvarez, M.I. Cegarra, E.O. Cristallini, S.M. Kay, G.L. Lo Forte, F.X. Pereyra, and D.J. Perez (Eds.), Geología de la Región del Aconcagua, provincias de San Juan y Mendoza, Buenos Aires. Anales 24: 59-137.

Álvarez, P.P., Benoit, S.V., and Ottone, E.G. 1994. Las formaciones Rancho de Lata, Los Patillos y otras unidades mesozoicas de la Cordillera Principal de San Juan. Revista de la Asociación Geológica Argentina 49: 123-142.

Arguijo, M., and Volkheimer, W. 1985. Palinología de la Formación Sierra Pintada, Jurásico Inferior, Neuquén, República Argentina. Descripciones sistemáticas. Revista Española de Micropaleontología 17: 65-92.

Arguijo, M., Volkheimer, W., and Rosenfeld, U. 1982. Estudio palinológico de la Formación Piedra Pintada, Jurásico Inferior de la Cuenca Neuquina (Argentina). Boletim Instituto de GeocienciasUSP 13: 100-107.

Armella, C., Cabaleri, N., and Leanza, H.A. 2007. Tidally dominated, rimmed-shelf facies of the Picún Leufú Formation (Jurassic/ Cretaceous boundary) in southwest Gondwana, Neuquén Basin, Argentina. Cretaceous Research 28: 961-979.

Arrondo, O.G., and Petriella, B. 1980. Alicurá, nueva localidad plantífera liásica de la Provincia de Neuquén, Argentina. Ameghiniana 17: 200-215. 
Bucefalo Palliani, R., Mattioli, E., and Riding, J.B. 2002. The response of marine phytoplankton and sedimentary organic matter to the early Toarcian (Lower Jurassic) oceanic anoxic event in northern England. Marine Micropaleontology 46: 223-245.

Bucefalo Palliani, R., and Riding, J.B. 1999. Early Jurassic (PliensbachianToarcian) dinoflagellate migrations and cyst paleoecology in the Boreal and Tethyan realms. Micropaleontology 45: 201-214.

Burckhardt, C. 1900. Profiles géologiques transversaux de la Cordillere Argentino-Chilienne. Stratigraphie et Tectonique. Annales del Museo de La Plata, Sección Geología y Minería 2: 1-136.

Candel, M.S., Borromei, A.M., Martínez, M.A., and Bujalesky, G. 2013. Palynofacies analysis of surface sediments from the Beagle Channel and its application as modern analogues for Holocene records of Tierra del Fuego, Argentina. Palynology 37: $62-76$.

Damborenea, S.E. 2000. Hispanic Corridor: its evolution and the biogeography of bivalve molluscs. In: R.L Hall, and P.L. Smith (Eds.), Advances in Jurassic Research. Transtec Publications, GeoResearch Forum 6: 369-380.

Damborenea, S.E., Echevarría, J., and Ros-Franch, S. 2013. Southern hemisphere palaeobiogeography of Triassic-Jurassic marine bivalves. Springer Briefs in Earth System Sciences 8, Springer Netherlands, $139 \mathrm{p}$.

Damborenea, S.E., and Manceñido, M.O. 1979. On the palaeogeographical distribution of the pectinid genus Weyla (Bivalvia, Lower Jurassic). Palaeogeography, Palaeoclimatology, Palaeoecology 27: 85-102.

De Ferrariis, C.I.C. 1947. Edad del arco o dorsal antigua del Neuquén oriental de acuerdo con la estratigrafía de la zona inmediata. Revista de la Asociación Geológica Argentina 2: 256-283.

Dellapé, D.A., Mombrú, C., Pando, G.A., Riccardi, A.C., Uliana, M.A., and Westermann, G.E.G. 1979. Edad y Correlación de la Formación Tábanos en Chacay Melehue y otras localidades de Neuquén y Mendoza. Obra Centenario Museo La Plata 5: 81-105.

Digregorio, J.H. 1972. Neuquén. In: A.F. Leanza (Ed.), Geología Regional Argentina, Academia Nacional de Ciencias, Córdoba, p. 439-505.

Dimieri, L., Fortunatti, N., and Nullo, F. 2005. Estructura duplex plegada en el frente montañoso de la Cordillera Principal, río Atuel, provincia de Mendoza. Revista de la Asociación Geológica Argentina 60: 644-650.

Doyle, P., Poire, D.G., Spalletti, L.A., Pirrie, D., Brenchley, P., and Matheos, S.D. 2005. Relative oxygenation of the Tithonian-Valanginian Vaca Muerta-Chachao formations of the Mendoza Shelf, Neuquén Basin, Argentina. Geological Society of London Special Publications 252: 185-206.

Falkowski, P.G., Schofield, O., Katz, M.E., van de Schootbrugge, B., and Knoll, A.H. 2005. Why is the land green and the ocean red? In: J. Young, and H. Thierstein (Eds.), Coccolithophorids: From molecular process to global impact. Springer-Verlag Berlin Heidelberg, Berlin, p. 429-453.

Fensome, R.A., MacRae, R.A., Moldowan, J.M., Taylor, F.R., and Williams, G.L. 1996. The early Mesozoic radiation of dinoflagellates. Paleobiology 22: 329-338.

García, V.M. 1998. [Reconstrucción paleoambiental en base a palinofacies de las Formaciones Los Molles, Lajas y Challacó (Jurásico Medio) en la Sierra de Chacaico y adyacencias. Cuenca Neuquina. Provincia de Neuquén. Argentina. Tesis Doctoral, Departamento de Geología, Universidad Nacional del Sur, Bahía Blanca, 204 p. Unpublished.].

García, V.M., Quattrocchio, M.E., Zavala, C.A., and Martínez, M.A. 2006. Palinofacies, paleoambientes y paleoclima del Grupo
Cuyo (Jurásico Medio) en la Sierra de Chacaico, Cuenca Neuquina, Argentina. Revista Española de Micropaleontología 38 : 269-288.

García, V.M., Zavala, C.A., and Quattrocchio, M.E. 1994. Relación entre análisis palinológico y análisis de facies. Aplicación al Grupo Cuyo (Jurásico Medio) en la Cuenca Neuquina. Revista de la Asociación Geológica Argentina 49: 184-195.

González-Amicón, O., and Volkheimer, W. 1982a. Datos palinológicos del Bayociano (Formación Cura Niyeu) de la Sierra de Chacai-Có, Cuenca Neuquina, Argentina. Boletim Instituto de Geociencias-USP 13: 108-115.

González-Amicón, O.R., and Volkheimer, W. 1982b. Palinología estratigráfica del Jurásico de Chacai-Co y adyacencias (Cuenca Neuquina, República Argentina). III: Descripciones sistemáticas de los palinomorfos de la Formación Cura Niyeu (Bayociano). Ameghiniana 19: 165-178.

Götz, A.E., Szulc, J., and Feist-Burkhardt, S. 2005. Distribution of sedimentary organic matter in Anisian carbonate series of $S$ Poland: evidence of third-order sea-level fluctuations. International Journal of Earth Sciences 94: 267-274.

Groeber, P. 1946. Observaciones geológicas a lo largo del meridiano $70^{\circ}$. 1, Hoja Chos Malal. Revista de la Asociación Geológica Argentina 1: 117-208.

Groeber, P., Stipanicic, P.N., and Mingramm, R.G. 1953. Mesozoico (Jurásico). Geografía de la República Argentina, GAEA 2: 541 p.

Gulisano, C.A., Gutiérrez Pleimling, A.R., and Digregorio, R.E. 1984. Esquema estratigráfico de la secuencia Jurásica del oeste de la provincia del Neuquén. $9^{\circ}$ Congreso Geológico Argentino (Bariloche), Actas 1: 236-259.

Gulisano, C.A., and Pando, G.A. 1981. Estratigrafia y facies de los depósitos jurásicos entre Piedra del Águila y Sañicó, Departamento Collon Cura, Provincia del Neuquén. $8^{\circ}$ Congreso Geológico Argentino (San Luis), Actas 3: 553-577.

Heinze, M. 1996. Paläobiogeographie jurassischer Muschelfaunen: Beziehung zwischen Süd-und Nordrand der Tethys. Paläontologische Zeitschrift 70: 97-128.

Hillebrandt, A. v. 1987. Liassic ammonite zones of South America and correlations with other provinces. With description of new genera and species of ammonites. In: W. Volkheimer (Ed.), Bioestratigrafía de los Sistemas regionales del Jurásico y Cretácico de América del Sur. Comité Sudamericano del Jurásico y Cretácico, Mendoza, 2: 111-157.

Hillebrandt, A. v. 2006. Ammoniten aus dem Pliensbachium (Carixium und Domerium) von Sudamerika. Revue de Paléobiologie 25: $1-$ 403.

Hillebrandt, A. v., Smith, P., Westermann, G.E.G., and Callomon, J.H. 1992. Ammonite zones of the Circum-Pacific region. In: G.E.G. Westermann (Ed.), The Jurassic of the Circum-Pacific. Cambridge University Press, Cambridge, p. 247-272.

Hogg, S.L. 1993. Geology and hydrocarbon potential of the Neuquén Basin. Journal of Petroleum Geology 16: 383-396.

Howell, J.A., Schwarz, E., Spalletti, L.A., and Veiga, G.D. 2005. The Neuquén Basin: an overview. In: G.D. Veiga, L.A. Spalletti, J.A. Howell, and E. Schwarz (Eds.), The Neuquén Basin, Argentina: A Case Study in Sequence Stratigraphy and Basin Dynamics. Geological Society, of London Special Publications 252, p. 1-14.

Iturralde-Vinent, M.A. 2004. La Paleogeografía del Caribe y sus implicaciones para la biogeografía histórica. Revista del Jardín Botánico Nacional 25-26: 49-78.

Iturralde-Vinent, M.A. 2006. Meso-Cenozoic Caribbean paleogeography: implications for the historical biogeography of the region. International Geology Review 48: 791-827. 
Katz, M.E., Finkel, Z.V., Grzebyk, D., Knoll, A.H., and Falkowski, P.G. 2004. Evolutionary trajectories and biogeochemical impacts of marine eukaryotic phytoplankton. Annual Review of Ecology, Evolution, and Systematics 36: 523-556.

Leanza, H.A. 1973. Estudio sobre los cambios faciales de los estratos limítrofes jurásico-cretácicos entre Loncopué y Picún Leufú. Provincia de Neuquén, República Argentina. Revista de la Asociación Geológica Argentina 28: 97-132.

Leanza, H.A., and Hugo, C.A. 1978. Sucesión de amonites y edad de la Formación Vaca Muerta y sincrónicas entre los paralelos $35^{\circ}$ y $40^{\circ}$ I.s. Cuenca Neuquina-Mendocina. Revista de la Asociación Geológica Argentina 32: 248-264.

Legarreta, L., Kozlowski, E., and Boll, A. 1981. Esquema estratigráfico y distribución de facies del Grupo Mendoza en el ámbito del sur mendocino de la cuenca Neuquina. $8^{\circ}$ Congreso Geológico Argentino (San Luis), Actas 3: 389-409.

Legarreta, L., and Uliana, M.A. 1991. Jurassic-Cretaceous marine oscillations and geometry of back-arc basin fill, central Argentine Andes. In: D.I.M. Macdonal (Ed.), Sedimentation Tectonics and Eustasy. International Association Sedimentologists Special Publication 12, Oxford, p. 429-450.

Legarreta, L., and Uliana, M.A. 1996. The Jurassic succession in west-central Argentina: stratal patterns, sequences and paleogeographic evolution. Palaeogeography, Palaeoclimatology, Palaeoecology 120: 303-330.

Legarreta, L., and Uliana, M.A. 1999. El Jurásico y Cretácico de la Cordillera Principal y la Cuenca Neuquina. In: R. Caminos (Ed.), Geología Argentina. Servicio Geológico Minero Argentino, Buenos Aires, Anales 29: 399-432.

Mantle, D.J. 2009. Palynology, sequence stratigraphy, and palaeoenvironments of Middle to Upper Jurassic strata, Bayu-Undan Field, Timor Sea region. Part two. Palaeontographica Abteilung B 280: 87-212.

Martínez, M.A. 1999. [Palinología estratigráfica del Jurásico del centrooeste de la Cuenca Neuquina. Tesis Doctoral, Departamento de Geología, Universidad Nacional del Sur, Bahía Blanca, 238 p. Unpublished.].

Martínez, M.A. 2002. Palynological zonation of the Lajas Formation (Middle Jurassic) of the Neuquén Basin, Argentina. Ameghiniana 39: 221-240.

Martínez, M.A., Olivera, D.E., Zavala, C., and Quattrocchio, M.E. 2016. Palynotaphofacies analysis applied to Jurassic marine deposits, Neuquén Basin, Argentina. Facies 62: 1-16.

Martínez, M.A., Prámparo, M.B., Quattrocchio, M.E., and Zavala, C. 2008. Depositional environments and hydrocarbon potential of the Middle Jurassic Los Molles Formation, Neuquén Basin, Argentina: palynofacies and organic geochemical data. Revista Geológica de Chile 35: 279-305.

Martínez, M.A., and Quattrocchio, M.E. 2004. Palinoestratigrafía y palinofacies de la Formación Lotena, Jurásico Medio de la Cuenca Neuquina, Argentina. Ameghiniana 41: 485-500.

Martínez, M.A., and Quattrocchio, M.E. 2005. Paleomicroplancton marino del Jurásico medio (Formaciones Los Molles, Lajas y Lotena) en el centro-oeste de la cuenca Neuquina, Argentina. Evaluación palinoestratigráfica y paleoambiental. Ameghiniana, Suplemento Resúmenes 42: 54R.

Martínez, M.A., Quattrocchio, M.E., and Prámparo, M.B. 2005. Análisis palinológico de la Formación Los Molles, Grupo Cuyo, Jurásico Medio de la cuenca Neuquina Argentina. Ameghiniana 42: 67-92.

Martínez, M.A., Quattrocchio, M.E., and Sarjeant, W.A.S. 1999. Jansonia psilata n. sp., a Middle Jurassic dinoflagellate from the
Neuquén Basin, Argentina. Revista Española de Micropaleontología 31: 255-263.

Martínez, M.A., Quattrocchio, M.E., and Sarjeant, W.A.S. 2001. Análisis palinoestratigráfico de la Formación Lajas, Jurásico Medio de la Cuenca Neuquina, Argentina. Revista Española de Micropaleontología 33: 33-60.

Mpodozis, C., and Ramos, V. 1989. The Andes of Chile and Argentina. In: G.E. Ericksen, M.T. Cañas Pinochet, and J.A. Reinemud (Eds.), Geology of the Andes and its relation to hydrocarbon and mineral resources. Circumpacific Council for Energy and Mineral Resources, Houston, Earth Sciences Series 11, p. 59-90.

Olivera, D.E., Martínez, M.A., Zavala, C., and Ballent, S.C. 2010. Los depósitos oxfordiano-kimmeridgianos de la Formación Lotena: nuevas perspectivas en la estratigrafía del Jurásico Tardío de la Cuenca Neuquina, Argentina. Ameghiniana 47: 479-500.

Parrish, J.T. 1992. Climatology and oceanology. In: G.E.G. Westermann (Ed.), The Jurassic of the circum-Pacific. Cambridge University Press, Cambridge, p. 365-379.

Quartino, B.J., Rinaldi, C.A., and Maisterrena, E. 1981. Tres casos argentinos de movimientos interestratales. $8^{\circ}$ Congreso Geológico Argentino (San Luis), Actas 3: 295-303.

Quattrocchio, M.E. 1980. Contribución al conocimiento de la palinología estratigráfica del Jurásico Superior en la Cuenca Neuquina. Opera Lilloana 31: 1-59.

Quattrocchio, M. 1984a. Palinología estratigráfica y aspectos paleoecológicos y paleoclimáticos de la Formación Cura Niyeu (Jurásico Medio) en Lohan Mahuida (Neuquén, República Argentina). $3^{\circ}$ Congreso Latinoamericano de Paleontología (Oaxtepec), Actas: 185-191.

Quattrocchio, M. 1984. Palinomorfos del Bajociano de Lohan Mahuida (Cuenca Neuquina, Argentina). Descripciones sistemáticas. $3^{\circ}$ Congreso Latinoamericano de Paleontología (Oaxtepec), Actas: 175-184.

Quattrocchio, M.E., Martínez, M.A., and Volkheimer, W. 2007. Las floras jurásicas de la Argentina. Publicación Especial de la Asociación Paleontológica Argentina 11: 87-100.

Quattrocchio, M.E., and Sarjeant, W. 1992. Dinoflagellate cysts and acritarchs from the Middle and Upper Jurassic of the Neuquén Basin, Argentina. Revista Española de Micropaleontología 24: 67-118.

Quattrocchio, M.E., and Volkheimer, W. 1990. Jurassic and Lower Cretaceous dinocysts from Argentina: Their biostratigraphic significance. Review of Palaeobotany and Palynology 65: 319330.

Riccardi, A.C. 2008. The marine Jurassic of Argentina: a biostratigraphic framework. Episodes 31: 326-335.

Riccardi, A.C., Damborenea, S.E., and Manceñido, M.O. 1990. Jurassic taxa ranges and correlation charts for the Circum Pacific: 3. South America and Antarctic Peninsula. Newsletters on Stratigraphy 21: 75-103.

Riccardi, A.C., Damborenea, S.E., Manceñido, M.O., and Ballent, S.C. 1988. Hettangiano y Sinemuriano marinos en Argentina. $5^{\circ}$ Congreso Geológico Chileno (Santiago), Actas 2: 359-373.

Riccardi, A.C., Leanza, H.A., Damborenea, S.E., Manceñido, M.O., Ballent, S.C., and Zeiss, A. 2000. Marine Mesozoic Biostratigraphy of the Neuquén Basin. Zeitschrift für Angewandte Geologie, SH 1: 103-108.

Riccardi, A.G., Westermann, G.E., and Elmi, S. 1989. The middle jurassic Bathonian-Callovian ammonites zones of the Argentine-Chilean andes. Geobios 22: 553-597.

Riding, J.B., Fedorova, V.A., and Ilyina, V.I. 1999. Jurassic and lowermost Cretaceous dinoflagellate cyst biostratigraphy of the 
Russian Platform and northern Siberia, Russia. American Association of Stratigraphic Palynologists Contributions Series 36: 179 p.

Riding, J.B., and Helby, R. 2001. Early Jurassic (Toarcian) dinoflagellate cysts from the Timor Sea, Australia. Memoir of the Association of Australasian Palaeontologists 24: 1-32.

Riding, J.B., Mantle, D.J., and Backhouse, J. 2010. A review of the chronostratigraphical ages of Middle Triassic to Late Jurassic dinoflagellate cyst biozones of the North West Shelf of Australia. Review of Palaeobotany and Palynology 162: 543-575.

Riding, J.B., Quattrocchio, M.E., and Martínez, M.A. 2011. Mid Jurassic (Late Callovian) dinoflagellate cysts from the Lotena Formation of the Neuquén Basin, Argentina and their palaeogeographical significance. Review of Palaeobotany and Palynology 163: 227-236.

Riegel, W. 2008. The Late Palaeozoic phytoplankton blackoutArtefact or evidence of global change? Review of Palaeobotany and Palynology 148: 73-90.

Rosenzweig, M.L. 1995. Species diversity in space and time. Cambridge University Press, Cambridge, $433 \mathrm{p}$

Scafati, L.H., and Morbelli, M.A. 1984. Nuevos datos palinológicos de la Formación Lajas. Jurásico medio de la cuenca Neuquina. $3^{\circ}$ Congreso Argentino de Paleontología y Bioestratigrafía (Corrientes), Actas: 73-105.

Sluijs, A., Pross, J., and Brinkhuis, H. 2005. From greenhouse to icehouse; organic-walled dinoflagellate cysts as paleoenvironmental indicators in the Paleogene. Earth-Science Reviews 68: 281-315.

Smith, P.L. 1983. The Pliensbachian ammonite Dayiceras dayiceroides and early Jurassic paleogeography. Canadian Journal of Earth Sciences 20: 86-91.

Stipanicic, P.N. 1966. El Jurásico de la Vega de la Veranada (Neuquén), el Oxfordiense y el diastrofismo diveseano (AgassizYaila) en Argentina. Revista de la Asociación Geológica Argentina 20: 403-478.

Stipanicic, P.N. 1969. El avance de los conocimientos del Jurásico argentino a partir del esquema de Groeber. Revista de la Asociación Geológica Argentina 24: 367-388.

Stipanicic, P.N., Rodrigo, F., Baulíes, O., and Martínez, C. 1968. Las formaciones presenonianas en el denominado Macizo Nordpatagónico y regiones adyacentes. Revista de la Asociación Geológica Argentina 23: 67-89.

Stipanicic, P.N., Westermann, G.E., and Riccardi, A.C. 1975. The Indo-Pacific ammonite Mayaites in the Oxfordian of the southern Andes. Ameghiniana 12: 281-305.

Stukins, S. 2011. [Spatial and temporal palynological trends in marginal marine depositional system: Lajas Formation, Neuquén Basin, Argentina. PhD dissertation, University of Aberdeen, Aberdeen, 139 p. Unpublised.].

Stukins, S., Jolley, D.W., Mcllroy, D., and Hartley, A.J. 2013a. Middle Jurassic vegetation dynamics from allochthonous palynological assemblages: an example from a marginal marine depositional setting; Lajas Formation, Neuquén Basin, Argentina. Palaeogeography, Palaeoclimatology, Palaeoecology 392: 117127.

Stukins, S., Mcllroy, D., and Riding, J.B. 2013b. Comparative biostratigraphy and palaeoenvironment analysis between the upper and lower Lajas Formation, Neuquén Basin from Portada Covunco and Sierra de Chacaico. Conference: AASP-TPS $46^{\text {th }}$ Annual Meeting (San Francisco).

Valentine, J.W. 1973. Evolutionary ecology of the marine biosphere. Prentice-Hall, Englewood Cliffs, New Jersey, 511p.

Van de Schootbrugge, B., Bailey, T.R., Rosenthal, Y., Katz, M.E.,
Wright, J.D., Miller, K.G., Feist-Burkhardt, S., and Falkowski, P.S. 2005. Early Jurassic change and the radiation of organic-walled phytoplankton in the Tethys Ocean. Paleobiology 31: 73-97.

Veiga, R.D., and Orchuela, I.A. 1988. Técnicas de perfilaje para identificar niveles generadores de hicrocarburos en la Formación Vaca Muerta. Boletín de Informaciones Petroleras, Tercera Época 13: 76-94.

Vergani, G.D., Tankard, A.J., Belotti, H.J., and Welsink, H.J. 1995. Tectonic evolution and paleogeography of the Neuquén Basin, Argentina. In: A.J. Tankard, R. Suarez Soruco, and H.J. Welsink (Eds.), Petroleum Basins of South America. AAPG Memoirs 62, American Association of Petroleum Geologists, Tulsa, p. 383402.

Volkheimer, W. 1973. Palinología estratigráfica del Jurásico de la sierra de Chacai Co y adyacencias (Cuenca Neuquina, República Argentina). I. Estratigrafía de las formaciones Sierra Chacai Co (Pliensbachiano), Los Molles (Toarciano, Aaleniano), Cura Niyeu (Bayociano) y Lajas (Caloviano Inferior). Ameghiniana 10: 105129.

Volkheimer, W. 1974. Palinología estratigráfica del Jurásico de la sierra de Chacai Co y adyacencias (Cuenca Neuquina, República Argentina). II. Descripción de los palinomorfos del Jurásico Inferior y Aaleniano (formaciones Sierra Chacai Co y Los Molles). Ameghiniana 11: 135-169.

Volkheimer, W., and Moroni, A. 1981. Datos palinológicos de la Formación Auquinco, Jurásico Superior de la Cuenca Neuquina. $8^{\circ}$ Congreso Geologico Argentino (San Luis), Actas 4: 795-812.

Volkheimer, W., and Quattrocchio, M.E. 1975. Palinología estratigráfica del Titoniano (Formación Vaca Muerta) en el área de Caichigüe (cuenca Neuquina). Parte A: Especies terrestres. Ameghiniana 12: 193-241.

Volkheimer, W., and Quattrocchio, M.E. 1977. Palinología estratigráfica del Titoniano (Formación Vaca Muerta) en el área de Caichigüe (cuenca Neuquina). Parte B: Especies marinas. Ameghiniana 14: 162-169.

Volkheimer, W., and Quattrocchio, M.E. 1981. Palinología estratigráfica de la Formación Lotena, Jurásico Medio de la Cuenca Neuquina. $8^{\circ}$ Congreso Geológico Argentino (San Luis), Actas 4: $761-775$

Volkheimer, W., Manceñido, M., and Damborenea, S. 1977. La Formación Los Patos (nov. form.), Jurásico inferior de la Alta Cordillera de la Provincia de San Juan (República Argentina), en su localidad tipo (Río de Los Patos Sur). Revista de la Asociación Geológica Argentina 32: 300-311.

Volkheimer, W., Manceñido, M., and Damborenea, S. 1978. Zur Biostratigraphie des Lias in der Hochkordillere von San Juan, Argentinien. Münstersche Forschungen für Geologie und Paläontologie 44: 205-253.

Volkheimer, W., Caccavari, M., and González-Amicón, O. 1981. Estudio palinológico de estratos liásicos en el borde austral de la Cuenca Neuquina. $8^{\circ}$ Congreso Geológico Argentino (San Luis), Actas 4: 777-793.

Weaver, C.E. 1931. Paleontology of the Jurassic and Cretaceous of West Central Argentina. Memoir of the University of Washington 1: 1-469.

Westermann, G.E.G. 1993. Global bio-events in mid-Jurassic ammonites controlled by seaways. In: M.R. House (Ed.), The Ammonoidea: Environment, Ecology and Evolutionary Change. The Systematics Association Special Volume 47: 187-226.

Zavala, C.A. 1996a. Sequence Stratigraphy in Continental to Marine Transitions. An Example from the Middle Jurassic Cuyo Group, South Neuquén Basin, Argentina. In: A.C. Riccardi (Ed.), Advances in Jurassic Research. Transtec Publications, GeoResearch Forum 
1-2, Zurich-Uetikon, p. 285-294.

Zavala, C.A. 1996b. High-resolution sequence stratigraphy in the Middle Jurassic Cuyo Group, South Neuquén Basin, Argentina. In: A.C. Riccardi (Ed.), Advances in Jurassic Research. Transtec Publications, GeoResearch Forum 1-2, Zurich-Uetikon, p. 295304.

Zavala, C. 2005. Tracking sea bed topography in the Jurassic. The Lotena Group in the Sierra de la Vaca Muerta (Neuquén Basin, Argentina). Geologica Acta 3: 105-116.

Zavala, C., and Freije, H. 2002. Cuñas clásticas jurásicas vinculadas a la Dorsal de Huíncul. Un ejemplo del área de Picún Leufú. Cuenca Neuquina, Argentina. $5^{\circ}$ Congreso de Exploración y Desarrollo de Hidrocarburos (Mar del Plata), Actas CD-Room, p. 14.

Zavala, C., and González, R. 2001. Estratigrafía del Grupo Cuyo (Jurásico Inferior-Medio) en la Sierra de la Vaca Muerta, Cuenca Neuquina. Boletín de Informaciones Petroleras 65: 40-54.

Zavala, C., Maretto, H., and Di Meglio, M. 2005. Hierarchy of bounding surfaces in aeolian sandstones of the Jurassic Tordillo Formation (Neuquén Basin, Argentina). Geologica Acta 3: 133-146.

Zavala, C., Arcuri, M., Gamero, H., Contreras, C., and Di Meglio, M. 2011. A genetic facies tract for the analysis of sustained hyperpycnal flow deposits. In: R.M. Slatt, and C. Zavala (Eds.), Sediment transfer from shelf to deep water. Revisiting the delivery system. AAPG Memoirs in Geology 61, American Association of Petroleum Geologists, Tulsa, p. 31-51.
Zavala, C., Arcuri, M., Di Meglio, M., and Zorzano, A. 2014. Depósitos de turbiditas intra y extra cuencales: origen y características distintivas. $9^{\circ}$ Congreso de Exploración y Desarrollo de Hidrocarburos (Mendoza), Actas 2: 225-244.

Zavattieri, A.M., Rosenfeld, U., and Volkheimer, W. 2008. Palynofacies analysis and sedimentary environment of Early Jurassic coastal sediments at the southern border of the Neuquén Basin, Argentina. Journal of South American Earth Sciences 25: 227-245.

Doi: 10.5710/PEAPA.25.11.2016.115

Recibido: 29 de abril de 2016

Aceptado: 25 de noviembre de 2016 